\title{
The impact of governmental intervention on the association between initial public offering and future stock issuance
}

\author{
Dimitrios Gounopoulos, Yilmaz Guney, Jingsi Leng, Victoria Patsika ${ }^{1}$
}

\section{Suggested citation:}

Gounopoulos, D., Guney, Y., Leng, J. and Patsika, V. (2020). The impact of governmental intervention on the association between initial public offering and future stock issuance. British Journal of Management, forthcoming.

\begin{abstract}
We examine the effect of initial public offering (IPO) characteristics on seasoned equity offering (SEO) decisions in relation to governmental intervention in China. Our results confirm the process of underpriced IPOs in promoting earlier and larger IPOs in the Chinese context. The study examines three channels through which the Chinese government intervenes in equity issuance activities named state ownership, politically connected executives and economic development areas. We find that the connection between IPOs and SEOs becomes less apparent in government-intervened firms. We attribute our results to the conflict between the state and minority shareholders, which leads to high uncertainty and risk in government-intervened firms.
\end{abstract}

JEL Classification: G30, G32

Keywords: Initial Public Offerings, Seasoned Equity Offerings, State-Owned Enterprises, Governmental Intervention, Political Connections, China

\footnotetext{
${ }^{1}$ We are grateful to Selim Chahine, Kalok Chan, Sandeep Dahiya, Arif Khurshed, Leora Klapper, Gary Koop, Daisy Li, David Newton, Paul McGuinness, Roni Michaeli, Jay Ritter, Geoff Wood (The Editor), seminar participants at the the University of Birmingham, the University of Hull, the Newcastle University and the University of Sussex. Comments from participants at the European Finance Association Meetings, Financial Engineering and Banking Society, Financial Management Conference, are also acknowledged. We are grateful to Jean Chen from Xian Jiatong-Liverpool University, Gary Zhou from Ernst and Young (ShenZhen), and Wu Qinq from Shanghai Stock Exchange for insightful discussions about Chinese laws and to Chen Huang, Hang Pham, and George Loukopoulos for excellent research assistance.
} 


\section{Introduction}

Welch (1989) states that firms with good prospects underprice IPOs to inform outsiders of their high quality and compensate the losses via an earlier and larger SEO (see also Jegadeesh et al., 1993). However, financial environment influences boundedly investors in interpreting information indicated by issuers (Park and Patel, 2015). Bayar et al. (2019), on a study examining the optimal disclosure around IPOs and SEOs, document that equity offering prices are affected by various rules governing disclosure around equity issues. ${ }^{2}$ The Chinese capital market is criticized by severe asymmetric information, agency conflicts and opaque disclosure (Bruton et al., 2015; McGuinness, 2018). More importantly, governmental interferences are still prevalent in China, as they play key roles in shaping equity issuing activities (Huang et al., 2016). These issues constitute additional impediments that lead firms to deviate from their optimal financing strategy and determine the ease and efficiency with which firms can access the capital markets (Bo et al., 2011). Previous studies advanced our understanding of the connection between IPO and SEO performances (Slovin et al., 1994; Ghosh et al., 2000; Francis et al., 2010), but their findings may not necessarily apply to the Chinese financial environment, which is unique- hence worthy of investigation- due to high governmental intervention in financial markets. In particular, whether and how state interference influences firms' equity issuance strategy collectively has not been fully addressed.

While governmental interference is not unique in the Chinese capital market, the role it plays in China is of particular interest (Farinós et al., 2007; Bruno et al., 2016; Behr et al., 2019). Firstly, Chinese government is more directly involved in business sector through its ownership in state-owned enterprises (SOEs), compared with its counterparties in other countries (Zheng et al., 2019). Although Chinese government has reduced its control over corporate sector through the establishment of two domestic stock exchanges and has encouraged the growth of private enterprises, SOEs still make a substantial contribution to the economic activity (Li et al., 2019). The existence of momentous state

\footnotetext{
${ }^{2}$ They are affected as well by demand from institutional investors with access to a costly disclosure verification technology; and demand from retail investors.
} 
ownership in listed firms makes it possible for government to influence corporate policies that favour state sector. Secondly, the Chinese government remains dominant on listed firms by influencing the appointment of top executives (Chen et al., 2011). Many firms in China have CEOs or chairpersons with political connections, who are either incumbents or previously held positions as government officers. These decision makers tend to take advantage of their positions to aid the government's objectives in return for a political promotion (Cao et al., 2019). Thirdly, the most important financing channel in China is still the banking system that is dominated by the four largest state-owned banks (Allen et al., 2005; Firth et al., 2016). Although the development of equity and bond markets in China provides firms with an alternative channel of financing, the largest state-owned banks supply more than $80 \%$ of commercial and industrial loans to corporations (Shao et al., 2015). The Chinese government maintains influence over enterprises and direct their growth path through its control on the financial providers. Finally, the governmental institutions, including the State-owned Assets Supervision and Administration Commission of the State Council (SASAC), take responsibilities to monitor the behavior of SOEs (Guo et al., 2017). By doing so, SOEs are scrutinised to utilise their ongoing activates to serve the public and promote social harmony.

Motivated by the governmental intervention standing in the Chinese market, which tends to influence corporate policies including equity issuances, this study aims to explore how state interference affects the interaction between IPOs and SEOs in China. We hypothesise that IPO underpricing is less likely to serve as an indicator of good prospects in firms with state involvement and therefore to connect with an earlier or larger SEO. Firstly, Chinese government intervention forces firms to accomplish social and political goals, including proving job to society, maintaining social stability and regional development. (Chen et al., 2011). The conflict between state and minority shareholders leads to investment inefficiency and therefore destroys corporate value. IPO underpricing in firms with state involvement can be a compensation of the expected inefficiency instead of a device to reveal good quality of firms. Moreover, state-owned firms underprice their stocks through SEOs for political and 
economic ends rather than to raise capital in the future (Jones et al., 1999). Chinese government targets privatizing SOEs and therefore underprices IPOs to show commitment to privatisation. As an example, Huolinhe Opencut Coal Ind as a SOE achieved a SEO in 2014 which is ten times of its IPO with the offering underpriced by approximately $168 \%$ whereas Luxshare Precision Industry Co Ltd, a non-SOE, achieved a SEO with similar size around the same time only underpriced its IPO by $39 \%$. By discounting offer price, the Chinese government intends to promote broader share ownership (Chen et al., 2015). Finally, having strong support from governmental institutions, access to bank debt is relatively easy for firms with state involvement (Sapienza, 2004), which mitigates their incentive to entice investors to raise capital from the following equity issues.

We consider three forms of governmental intervention in this study. The first form is state ownership of corporations in China. Existing studies suggest that high level of state ownership is often connected with political-and social-oriented objectives and decisions facilitating social and political goals instead of maximising firm value (La Porta et al., 2002; Chen et al., 2008; Firth et al., 2010). Gul et al. (2010) document that firms with state ownership experience inefficient corporate governance and share price informativeness, and therefore can potentially destroy the benefits of minority shareholders (Hou et al., 2012; Xia and Walker, 2015). ${ }^{3}$ In China, state is not only the major shareholder of many corporations but also the principal owner of large banks. This dual ownership allows the government to administer the behaviour of banks to the direction of making preferential loans to firms with high state ownership. Although most SOEs are partially privatised, they are still under the control of the government to carry out activities as required by the state or even undertake value-reducing projects.

\footnotetext{
${ }^{3}$ Family ownership has become a topic of interest in the event of IPOs, which is in relation to both financial wealth and social emotional wealth. For example, Kotlar et al. (2018) investigated the IPO underpricing phenomena in family firms focusing on European IPOs. Hülsbeck et al. (2019) also investigate the determinant of firm performance in family using IPOs in Germany. However, unlike the scenario in Europe and other countries in Asian such as India, China is characterized by the "absence of families as significant shareholders" (Tenev and Zhang, 2002). Li and Qian (2013) suggest that the ownership structure of listed companies in China is not dominated by families; instead, it is highly influenced by political connection and state ownership (Fan et al., 2007).
} 
The second form of state interference is political-connected executives of firms. Chinese listed firms differ from their counterparties in other countries in that there is prevalent political connection of senior management (Cohen and Dean, 2005; Fan et al., 2007). The government retains its influence on corporations through its control on the appointed top executives. Politically connected managers seek to get political promotions or increase their social status by fulfilling the requirements of local/central government (Chen et al., 2017). Therefore, firms with politically connected managers are more likely to intervene and engage in activities that achieve government's objectives but not maximise firm value. Moreover, politically connected firms benefit from access to bank loan with better terms. However, this benefit may vanish with politicians' turnover. The uncertainty of economic source associated with politically connected managers further weakens the confidence of investors in equity issuances.

The third form of government intervention considered in this study is the locations strategically selected by the Chinese government (Almazan et al., 2010). During the economic reforms, Chinese government has strategically established economic development areas that cover 11 major cities with the purpose of setting them as economic engines to drive the economy nationally (Pan and Chi, 1999; Liu et al., 2019). While these economic areas receive the preferential treatments from central government and succeed to boost the national economy, they also serve as the wheel of the economy that directs the path of the economic development and follows the government policies more closely (Chen et al., 2013). This is an indirect governmental intervention that generates state influence on both the macroeconomic indicators and the corporate sector. It would be interesting to analyse how this indirect intervention affects firms' IPO and SEO strategy collectively.

Our study scrutinises information about the public firms' first SEOs from the perspectives of the IPO characteristics. Supporting Jegadeesh et al. (1993), we find that firms with higher IPO underpricing are more likely to issue subsequent SEOs and raise more proceeds in China. To disentangle the channels leading to governmental intervention, we collect information on the state ownership, political connection and the location of firms. After conducting a series of tests, we document that firms can 
achieve an earlier and larger SEO if their IPO shares are undervalued: these finding are more apparent when the firms are not controlled by the State, their managers are not politically connected or their headquarters are outside the economic development areas.

This study makes important contributions to the literature in relation to IPOs process and subsequent SEOs decisions as well as regarding the importance of governmental influence. Initially, we confirm the promoting effect of IPO underpricing on SEO issuance. We find that underpriced IPOs are positively connected to time and size of SEOs in a transition economy; thus, adding new evidence to this strand of literature. Secondly, our findings reflect the role of government in firms' equity issuance activities because of conflicts between state stakeholder and outside minority shareholders, which enhances our understanding of governmental interference in transition economies. There is a growing interest in the outcome of governmental intervention from finance and management research recently. For example, Faccio (2006) and Lazzarini (2015) suggest that governmental involvement creates comparative advantages and enhances firm value. However, Fan et al. (2007) and Deng et al. (2017) provide contrary evidence and find that government-intervened Chinese firms experience low investment efficiency and poor performance compared with their peers. We conjecture that the investment behaviour of government-intervened Chinese firms are distorted by state objectives derived from maximising firm value, which makes their post-IPO behaviour uncertain with high risk. Finally, this study contributes to the literature by exploring different forms of governmental intervention; namely, state ownership, political connection and location. We provide evidence that the Chinese government can influence IPO and SEO decisions from various channels. If the government determines to enhance efficiency of its capital market, it should eliminate its influence from difference perspectives.

Mapping our work to the extant literature, this study is related to Chen et al. (2011), Bruton et al. (2015) and Chan et al. (2017). Jia et al. (2019) and Bruton et al. (2015) highlight that SOEs are underexplored and they encourage scholars to contribute on their richer understanding. We take this opportunity and by using a comprehensive sample of IPOs \& SEOs, as well as by considering the critical 
role of the Chinese state in the enterprises with ownership, we offer evidence on the associated relationships. Chen et al. (2011) examine whether government intervention distorts firms' investment behaviour and leads to investment inefficiency. We extend their work by exploring the role of the governmental authorities in influencing equity financing strategy. We also examine and offer new evidence on the link between the level of uncertainty, agency conflicts in SOEs and the level of underpricing. Overall, the findings of this study are consistent with the prediction that firms underprice IPOs to facilitate an earlier and larger SEO and support the notion that state objectives and intervention affect the pattern of listed firms that desire to raise capital from the Chinese equity markets.

The rest of the paper is organised as follows. The hypotheses are developed in section 2 . The sample and methods are explained in section 3, while section 4 presents the empirical results. The robustness of the results is tested in section 5. Section 6 concludes the paper.

\section{Related literature and hypothesis development}

Existing literature predicts that firms with underpriced IPOs are more likely to conduct SEOs sooner and raise larger proceeds through their following issuances (Welch, 1989; Jegadeesh et al., 1993; Ghosh et al., 2000). It suggests that managers who have superior knowledge of the firms' true value have incentives to underprice their IPOs as a signal of outstanding performance to distinguish themselves from low-quality firms. Since IPO underpricing, on its own, is costly due to discounted capital raised from the market, a firm will only underprice its stocks when it attempts to recompense its losses using a higher price and a larger proceed through an SEO (Welch, 1989). Slovin et al. (1994) and Ghosh et al. (2000) also document similar results and report that firms with good prospects underprice their IPOs to show their confidence in future performance and compensate the losses via successful SEOs later (Chemmanur, 1993). Bonardo et al. (2010) provide evidence on science-based IPOs and indicate that they are associated with low operational efficiency (Meoli et al., 2013; Colombo et al., 2019). Information regarding a firm's key technologies, human capital and growth opportunities is probably not symmetrically disseminated to buyers (Ragozzino and Reuer, 2011). The seller (i.e., 
science-based company) may fail to reveal its true value and face a credibility problem (Ravenscraft and Scherer, 1988). Underpricing, which is a costly proposition for IPO firms, is identified as a tool to differentiate these firms from others, and therefore, brings benefits to the market by attracting better deals during the process (Park et al., 2016).

However, the institutional environment influences boundedly investors in interpreting information indicated by issuers (Park and Patel, 2015). In China, the government plays conflicting dual roles of administrator of social affairs and owner of SOEs. Chinese government is supposed to maximise the value of its firms as the owner. Holding the administrator role on social affairs, conversely, Chinese government is motivated to enhance SOEs' political capital to accomplish social and political goals, even at the cost of firm value reduction of SOEs. Guo et al. (2016) and Guo et al. (2017) state that SOEs are scrutinised to utilise their ongoing activates to promote social harmony under the monitor of governmental institutions. In other words, Chinese government inevitably alters the economic objectives of SOEs to achieve policy-oriented targets, such as maintaining social, economic and political stability and directing the development of the economic growth (Chen et al., 2008).

The political motivation of government-intervened firms raises the suspicion of investors on the information released by IPO underpricing. Firstly, an underpriced IPO issued by firms with governmental intervention is more likely to be the compensation for predicted political-oriented activities instead of a sign of good quality since investors perceive the high possibility of wealth expropriation in government-intervened firms. The recent law and finance literature highlights that a central agency problem in a setting like China with strong state involvement and weak investor protection is the expropriation of minority shareholders by controlling shareholders (Yuan et al., 2009; Latham and Braun, 2010). In particular, government tends to make firms' investment behaviour "propolicy", even at the costs of their financial performance (Piotroski and Zhang, 2014). Chen et al. (2011) argue that firms under governmental inference have poor post-IPO performance due to high level of agency costs, where government intervenes to achieve social and political goals. This behavior may, 
therefore, alter firms' investment decisions and reduce performance (Fan et al., 2007). Secondly, one of the political objectives of Chinese government is to privatise SOEs and drive the vibration of capital market. By discounting offer price, the Chinese government may just intend to promote broader share ownership and show its commitment to privatisation (Chen et al., 2015). Finally, governmental intervention brings uncertainty to firms' behaviour and diminish the credence of signal sent by underpriced IPOs.

A firm may discount offer price during the process of IPO since it is confident in its prospective future. However, the firm may also give away its investment opportunity to accomplish the requirement of policy changes. Deng et al. (2011) document that firms with a governmental connection are loyal to the state and tend to make their behaviour "pro-policy". Government-intervened firms are more willing to comply with state requirements, respond quickly to changes in the economic strategy and therefore influenced more by policy-related uncertainty (Huang et al., 2011). Byeongju (2002) states that uncertainty related to policy can raise expected costs and distort long-term investment. Moreover, uncertainty stemming from policy changes defers the reaction of SOEs for upcoming investment opportunities, since they tend to await the confirmation from government to ensure the new investment is in accordance with policy directions (Rodrik, 1991).

Based on the discussion above, we expect that the government intervention in Chinese firms moderates the association between of IPO underpricing and SEO issuances as compared to nonintervened firms. We consider three government intervention forms and develop hypotheses as below.

\subsection{State Ownership, IPO Underpricing and SEO Issuances}

Corporate ownership evidence (Hill, 2006; Kroll et al., 2007; Bruton et al., 2010; Lungeanu and Zajac, 2016; Connelly et al., 2019) suggests that corporate owners create identifiable and evolving differences in their expertise. When coordinating these differences to firms' specific and changing strategic needs, there will be a source of value over the life cycle of a firm. Matching theory suggests that the ownership changes can enhance a firm's performance especially when the firm is with low 
productivity (Lichtenberg and Siegel, 1990; Bloom et al., 2010).

Existing studies also provide evidence on the effect of state ownership on multiple decisions of firms. For instance, Borisova and Megginson (2011) and Borisova et al. (2015) examine how state ownership affects firms' borrowing decisions and cost of debt. Borisova et al. (2012) document that governmental ownership in firms is associated with lower corporate governance quality. Thomsen and Pedersen (2000) support that the identity of government owners has important implications for corporate strategy and performance.

State ownership in China has also strong implications for corporate operations. Chen et al. (2011) suggest that state ownership in Chinese firms undermines performance since SOEs may undertake value-reducing investments to fulfil social and political objectives. Chen et al. (2017) use the highpower setting and provide evidence on the important role of state ownership in determining firms' investment strategy. Chen et al. (2004) argue that firms with state ownership have poor post-IPO performance due to high level of agency costs in SOEs, where government intervenes to achieve social and political goals. Xu et al. (2014) confirm the poor transparency in Chinese SOEs and report that the managers of these firms have great incentives to withhold bad news to the market to enjoy high stock prices, which can end up with a significant risk in price crash. Li and Tang (2010) argue that SOEs' operational strategies are constrained by the state and hence managers have little discretion to make their own decisions and undertake profitable projects. Chen et al. (2011) support the idea that social and political roles of SOEs in China reduce investment efficiency.

Existing literature shows clear evidence that state ownership leads to governmental interference in corporate operation and management (Sun et al., 2002). Therefore, we propose that the direct connection between IPO underpricing and SEO issuances, which is explored and shown by the extant literature, becomes weak in state-owned or influenced Chinese firms since IPOs fail to deliver signs of good quality to investors due to the uncertainty related to governmental intervention.

Hypothesis 1. State ownership weakens the positive association of IPO underpricing with the SEO proceeds or with the likelihood of conducting subsequent SEOs. 


\subsection{Political Connections, IPO Underpricing and SEO Issuances}

To distinguish between firms with low or high governmental intervention, this study also measures the degree of state interference by checking whether the companies employ politically connected managers. Chinese government maintains its influence on some listed firms by appointing top executives and offer these managers with political promotions to serve for the benefits of the state (Shleifer and Vishny, 1994; Hung et al., 2012). The politically connected directors help firms to gain preferential treatments from state-owned banks, attract more governmental contracts, are given relaxed regulatory monitor and receive aids in case of financial trouble (Chizema et al,. 2015). However, it is inevitable that politically connected executives carry out government policies and agendas to fulfil social and political objectives, which are the basis of the evaluation of their performance and future promotions in their career as politician. Li and Tang (2010) argue that SOEs' operation strategies are constrained by the state while managers have little discretion to make their own decisions and undertake profitable projects. Similarly, the political resource of the senior management becomes the capital to enhance their power on the corporate operation and intensifies the intervention behaviour of the government. Fan et al. (2007) state that politically connected firms are more willing to undertake government-oriented activities and therefore under-perform their counterparties without political ties (see also Chen et al., 2018).

Overall, the above discussion suggests that firms with political connections are more obliged and motivated to achieve social and political goals under the influence from government, compared to their non-politically connected peers. To this end, the post-IPO investment of firms with connections is expected to be less efficient and with high uncertainty, which lowers the effect of IPO underpricing.

Hypothesis 2. Political connection of firms has a moderating effect on the positive association of IPO underpricing with the SEO proceeds or with the tendency to conduct a subsequent SEO. 


\subsection{Location, IPO Underpricing and SEO Issuance}

Existing studies suggest that geographical location has important influence on a firm's financial decisions. For instance, John et al. (2011) find that firms' location play a role in determining dividend policy. Almazan et al. (2010) document that firms in high-tech and growing cities have greater investment opportunities than their peers and maintain more financial slack. Nielsson and Wójcik (2016) show that firms' location is associated with IPOs performance.

The establishment of economic development areas in China leads to economic disparities across regions. These differences are caused by the government's development strategies and subsequent variation in investment opportunities. For example, Chinese government designs the location-based tax incentives to drive innovation and economic growth in economic development areas (Pan and Chi, 1999; Liu et al., 2019). The preferential treatment from the government on firms in selected areas aims to boost the national economy, serves as the wheel of the economic development and therefore requires located business follow the strategic policies implemented by the government (Chen et al., 2013).

We propose IPOs fail to deliver signs of good quality to investors due to the uncertainty related to indirect governmental interference resulted from firms' location. For example, the fast growing economy in economic development areas may bring about great growth opportunities, which causes overinvestment of firms nearby. Moreover, firms in governmental supported areas are more likely to receive preferential treatments from state banks and therefore have financial slack, which may lead to more severe agency conflicts.

Hypothesis 3. Firms located in economic development areas experience reduced positive association of IPO underpricing with the SEO proceeds or with the likelihood of conducting subsequent SEOs. 


\section{Data and Methods}

\subsection{Data Construction}

Our main data source is Shenzhen GTA Information Technology Co. We first collect all IPOrelated characteristics from the IPO database (A share) with the IPO offer date between 1990 and 2015. The market data are from CSMAR Stock Market Databases. To ensure the market performance is postIPO, IPO characteristics and market performance are merged based on the equity ID provided by Shanghai and Shenzhen stock exchanges and IPO offer date, which yields 1,851 IPOs with IPO characteristics available. We then drop the IPOs initiated after 2012 as we require data on SEOs for the three-year period after the IPO and our SEO information is available to the end of 2015. This gives us 1,708 IPOs. Based on the IPO list prepared above, we further add SEO information obtained from the Seasoned Equity Offering Database. In particular, 804 firms out of 1,708 IPOs between 1990 and 2012 have records of issuing SEOs. In the final step, we include corporate governance data from Corporate Governance Structure Database.

\subsection{Models}

Our basic model inspired by Jegadeesh et al. (1993), Spiess and Pettway (1997), Clinton et al. (2014) and Vithanage et al. (2016) is below:

SEO Time $_{i}($ SEO Relative Size $i)=\alpha+\beta_{1}$ IPO Underpricing ${ }_{i}+\beta_{2}$ Shanghai $_{i}+\beta_{3}$ Abnormal return_ $1_{i}+\beta_{4}$ Abnormal return_2 $2_{i}+\beta_{5}$ Market Momentum $+\varepsilon_{i}$

The dependent variables are SEO Time (Eq. 1) and SEO Relative Size (Eq. 2). SEO Time is a dummy variable: 1 if a firm issues its first SEO within three years of IPO; 0, otherwise. SEO Relative Size is SEO size to IPO size. To investigate the association between IPO underpricing and SEO performance, we resort to our main explanatory variable IPO Underpricing as the percentage difference between closing price on the IPO day and IPO offer price divided by the IPO offer price. We also consider several control variables. We introduce unexpected aftermarket returns in two separate 20-day periods after IPO (i.e., Abnormal return_l and Abnormal return_2), following Jegadeesh et al. (1993) 
and Spiess and Pettway (1997). Stock exchange dummy (i.e., Shanghai) controls which stock exchange the firm is listed in. Finally, Market Momentum controls for the market-wide behavior (Cornelli et al., 2006).

IPO underpricing is potentially endogenous and associated with many other variables (Brennan and Franks, 1997; Lowry and Shu, 2002; Liu and Ritter, 2011). Jegadeesh et al. (1993) suggest that the explanatory power of IPO underpricing could be driven by the correlation between SEOs and other factors influencing IPO underpricing. Following Edmans et al. (2012) and Gounopoulos et al. (2017), we first employ the efficient full information maximum likelihood (MLE) to control the effect of IPO underpricing determinants on SEO decisions. Moreover, we conduct two-stage instrumental variables (IV) approach following Newey (1987), where IPO underpricing is instrumented at the first stage to control the potential endogeneity issue. We employ IPO oversubscription as an instrument for IPO underpricing. Brennan and Franks (1997) show that underpricing is used to ensure oversubscription and rationing in the share allocation process so as to allow owners to discriminate between applicants of shares. Lee et al. (1996) make a step further and examine the relationship between long-run returns and initial demand (oversubscription). Cornelli and Goldreich (2003) document that oversubscription and demand elasticity are positively correlated with the first-day aftermarket return, and oversubscription is unrelated with aftermarket performance. Overall, IPO oversubscription evidently (Chowdhry and Sherman, 1996; Francis et al., 2009; Thomadakis et al., 2016) is significantly related with IPO underpricing but is irrelevant with the decision of a company to go on a follow-up SEO. The correlation analysis in table A2 also shows that IPO oversubscription is significantly correlated with IPO underpricing but not correlated with SEO performance. ${ }^{45}$

\footnotetext{
${ }^{4}$ As a general note, the correlation tests and variance inflation factors (VIFs $<10$ ) confirm the absence of the multicollinearity problem among the regressors in all models in this study.

${ }^{5}$ To test the validity of IPO oversubscription as an instrumental variable, we regress IPO underpricing on IPO oversubscription. We find that IPO oversubscription is significantly related to IPO underpricing even after controlling for the exogenous regressors, which confirms the strength of our instrument. In addition, we regress the error term from the structural equation on IPO oversubscription. The insignificant coefficient on IPO oversubscription suggests the exogeneity of the instrument.
} 
As all the SEOs variables are based on the first seasoned equity offering, the standard logit/probit/tobit or OLS results may be subject to self-selection bias given that only firms with SEOs are included in the sample. To address this issue, we apply Heckman's (1979) two-stage procedure. We first estimate a logistic model, where the decision to reissue stocks is the dependent variable and regressed against the variables described in the basic model. In the second stage, we use OLS corrected for self-selection bias to investigate the association between SEO relative size and predictor variables. All variables are defined in the Appendix.

\section{Empirical Results}

\subsection{Summary Statistics}

The descriptive statistics of our variables are summarised in table 1. We observe that IPOs underpricing level is, on average, $98.0 \%$ for the total sample of firms (i.e., conducted/or not their first SEOs - Panel A). However, when we consider the IPOs followed by SEOs only, the underpricing rises to 135\% (Panel B). This is in line with the elucidation that firms deliberately underprice their IPOs as they plan to conduct an SEO in the near future. In addition, we find that firms owned by the state account for 36.7 percent of firms in our full IPO sample. Similarly, there are 35.9 percent of firms in China are with political connection. The large number of state-owned or politically connected firms indicates the strong intervention of Chinese government in its capital market and provides us with a unique natural experiment to investigate whether the political element affects firms' behavior in seeking external capital. Interestingly, we observe in our sample that the average IPO oversubscription rate is 274 times: this high figure is mainly caused by high demand on a limited supply of shares and inadequate opportunities for investment in Chinese capital market (Yu and Tse, 2006). ${ }^{6}$

Table 2 provides the annual time series of IPO and SEO occurrences covered by our sample. There is substantial time variation in IPO volume following the development of the Chinese stock

\footnotetext{
${ }^{6}$ The maximum value in our sample is 1126. Our statistics are comparable to i) Fan and Zhang (2007) who report 981 as the $95^{\text {th }}$ percentile value during January 2000-June 2002 in China; ii) Gao (2010) who reports a mean value of 1009 between 2006 and 2008; iii) Tian (2011) who finds a mean value of 254 during 1992-2004.
} 
market and regulatory changes. Specifically, there is no IPO issued in 2013 because the Chinese Security Regulatory Commission placed a freeze on Chinese IPOs from November 2012 to December 2013. The number of SEO issuances also varies across time, which is partially affected by regulation changes in the Chinese capital market. ${ }^{7}$ The overall trend of SEO proceeds increased. Finally, we observe that SEOs' relative size has remained stable since 1997 and, on average, the first time SEO proceeds are larger than the IPO proceeds of a firm. This further indicates the importance of the SEOs in China as a process to raise capital.

Table 3 presents the descriptive statistics according to the classification of firms' SEO and IPO strategies. Firms are divided in panel A into two sub-samples based on whether they have issued SEOs within three years after IPOs, namely "IPOs with SEO" and "IPOs without SEO". "IPOs with SEO" record an average IPO underpricing of $147 \%$. This accounts for almost double the level of IPO underpricing of "IPOs without SEO", which is $81 \%$. Panel B presents descriptive statistics of underpriced/overpriced IPOs. On average, 27\% of underpriced IPOs issue SEOs within three years of initial offering, while the number drops to $16 \%$ in the overpriced group. This suggests that firms are more likely to issue an SEO following an underpriced IPO. Moreover, SEOs' relative size of underpriced IPOs is, on average, larger than the overpriced IPOs.

\subsection{The Impact of IPO Underpricing on SEO Activity}

Panel A of table 4 reports the empirical results on the association between IPO underpricing and the likelihood of issuing SEOs for the full sample of firms $(\mathrm{N}=1,708)$. We reserve column (1) for the logistic estimation to facilitate benchmarking. To demonstrate the robustness of our results, we present the regression findings from two other estimation methods: full information MLE in column (2) and IV approach in column (3). All regressions account for year- and industry-fixed effects.

Consistent with the findings of Jegadeesh et al. (1993), all three estimations generate highly

\footnotetext{
${ }^{7}$ For example, SEO activity market in China before 2001 was substantial. However, the propensity changed dramatically in 2002, when CSRC introduced a requirement of a ROE $\geq 10 \%$ in three years before SEOs.
} 
significant coefficients at the $1 \%$ level on IPO Underpricing and confirm that firms with IPO underpricing are more likely to issue SEOs earlier. By calculating the average marginal effect of IPO underpricing using IV estimation, we find that one unit increase in IPO underpricing accounts for an $8.9 \%$ higher probability of issuing SEO within three years after IPO for the average firm. Considering the overwhelming IPO underpricing in China, which is averaged at $98 \%$, this incremental effect is not negligible. We also observe a positive relationship between post-IPO abnormal return and the likelihood of SEO issuances. This suggests that firms are more likely to issue SEOs once they experience aftermarket price appreciation (Jegadeesh et al., 1993). The Hausman test obtained from the IV estimation rejects the null hypothesis of no endogeneity and strongly suggests the correlation of residual terms in the first stage regression. The instrumental variable, IPO Oversubscription, is significantly related to IPO underpricing.

In panel B of table 4, we examine the relationship between the IPO underpricing and relative size of SEOs. We include the same covariates as previously and make use of SEO Relative Size as the dependent variable in all models. Consistent with Welch's (1989) theory, the coefficients of IPO Underpricing clearly highlight the effect of IPO underpricing, which facilitates firms to raise additional capital from the stock markets. On average, an additional 10\% IPO underpricing increases SEO relative size by $3.99 \%$. Since the SEO relative size is the ratio of SEO proceeds to IPO proceeds, this $3.99 \%$ increase translates into a 30.60 million CNY value enhancement in SEO issuance for a mean-size IPO.

In table 5, we focus on subsample of firms with follow-up issuance only and assess the effect of IPO underpricing on relative SEO proceeds by using OLS, IV and Heckman methods. The direction of the respective coefficient is consistent with the results from the previous table and it further strengthens our estimation regarding the relationship between IPO underpricing and SEO relative size. The findings pertaining to the SEO characteristics align with our expectation. We obtain a positive and highly significant coefficient on SEO Leverage, which implies the substitution between debt and equity financing. This is consistent with the trade-off theory contends that firms may use equity issues to adjust 
their capital structure to maintain the optimal level of debt. The significant and positive coefficient on Market-to-Book prior to the first SEO suggests that firms tend to conduct larger SEOs when they have higher market-to-book ratios, which is perceived by the market as good growth prospects (Loughran and Ritter, 1995).

Following Filatotchev (2006), further, we consider the relevance of corporate governance in table 5. Interestingly, we find that good corporate governance significantly enhances SEO accomplishment. We observe that large boards and those with more independent directors - a proxy for corporate governance quality_increases SEO relative size. Higher ownership concentration, a metric for monitoring role on managers, is positively related to higher SEO proceeds. However, higher level of management entrenchment, measured by CEO Ownership is not significantly related to SEO relative size.

To control for the potential selection bias of the SEOs sample, we implement Heckman twostage procedure and present the results in column (3) of table 5. Initially, the coefficient on the Inverse Mill's ratio exhibits statistical significance at the $1 \%$ level, lending support to firms' self-selection into SEOs. Secondly, the coefficient estimate on IPO Underpricing remains significant and is positively related to SEO relative size, evidencing the promoting effect of IPO underpricing on SEO activities.

\subsection{Differential Impacts of IPO Underpricing with versus without Governmental Intervention}

In table 6-8, we examine how IPO underpricing influences timing and size of SEO for firms with versus without governmental intervention. We explore three channels through which the government can influence the behavior of firms: state ownership, political connections and location.

In table 6, we divide firms into state owned and non-state owned subgroups as per the variable State Owned and present the regressions to investigate the relevance of state ownership in the relationship between IPO underpricing strategies and subsequent SEO decisions, noting that State Owned is related to the effective role of the government in selecting the board and hence in influencing corporate decisions. Moreover, we introduce an interaction term between IPO underpricing and State 
Owned to observe directly their interrelation with SEO activities. The dependent variable in panel A of table 6 is SEO Time. We employ the IV estimation technique and the results show that the positive coefficient estimates on IPO Underpricing are only observed among non-SOEs in column (2). This strongly indicates that IPO underpricing is more likely to be related to SEO initiatives among firms not owned by the state. The results incorporating interaction between IPO underpricing and the state influence appear in column (3). We observe that State Owned on its own increases the likelihood of SEOs occurrence. This corroborates our expectation that in China the supply of shares is tightly controlled by the government and companies can only issue additional shares with approval from Chinese Securities Regulatory Commission (CSRC) (Chen and Wang, 2007). State-controlled firms have free access to the share capital with governmental support and therefore issue SEOs more frequently (Firth et al., 2010). More importantly, we find a significantly negative coefficient on the interaction term between IPO underpricing and State Owned, which suggests that effective state ownership and control reduces the effect of IPO underpricing on SEO activities.

The dependent variable in panel B is SEO Relative Size. The results demonstrate that firms with higher IPO underpricing tend to issue larger SEOs irrespective of the type of their major owners as the coefficients on IPO underpricing in columns (4) and (5) are both significant at the $1 \%$ level. The coefficient estimates on the interacted term between IPO underpricing and State Owned in column (3) is negative and significant, which implies that non-SOEs are more likely to recoup their loss from IPO underpricing by issuing larger SEOs as the positive effect of underpricing is reduced for firms with state influence. This reinforces our prediction that the implementation of IPO underpricing strategy correlates with the ownership and influence of the government in the firm.

Table 7 follows the similar structure as in table 6 and divides firms into subgroups based on whether the firms employ politically connected executives. By estimating the association between IPO underpricing and SEO activities with and without political connection separately, we investigate how governmental intervention through politically connected managers influences the effect of IPO 
strategies. Columns (1), (2), (4) and (5) all show positive coefficients on IPO underpricing, which indicate that higher levels of IPO underpricing tend to be followed by an earlier and larger SEO regardless of political connectedness. The interaction terms between Political Connection and IPO underpricing in columns (3) and (6) reveal significantly negative coefficients, which indicates that politically connected managers weakens the association between underpriced IPOs and SEO time/size. Taken together, these findings support our hypothesis that political connectedness as one form of state intervention reduces the link between IPO underpricing and follow-up SEOs.

Table 8 uses the geographical location (economic development area, EDA) to differentiate between firms with and without governmental interference. For the EDA subsample in panel A where the dependent variable is SEO Time, the insignificant coefficient on IPO underpricing suggests inefficiency of IPO strategy on the timing of SEOs. On the contrary, the same coefficient is significantly positive for the non-EDA subsample. This demonstrates an association between IPO underpricing and an earlier SEO for firms based in cities other than 11 cities (see notes in table A1). More importantly, the interaction term between IPO underpricing and Location is significantly negative at the 5\% level, which means that SEO time is significantly less sensitive to price of initial issuance in firms under governmental intervention based on location. The negative coefficient on the interacted term also suggests that the positive impact of IPO underpricing on SEO time is reduced for the EDA-firms.

The dependent variable in panel $\mathrm{B}$ of table 8 is SEO Relative Size. The estimated IPO underpricing coefficients for EDA- and non-EDA-firms are both significant and positive. Moreover, we find a significantly negative interaction term between IPO underpricing and Location in column (6), which suggests that the positive association between IPO underpricing and SEO relative size becomes weaker for firms located in the government intervening areas.

In summary, the results from tables 6-8 support our hypothesis of the mitigating effect of government intervention on the impact of underpriced IPO on SEOs through state ownership, political connection and specific locations. 


\section{Additional Robustness Tests}

\subsection{Alternative Specifications and Measurements}

To assure the robustness of our results, we undertake additional analyses. In table 9, we classify a firm as "SOE" if there is any state shareholdings within this firm, which is different from the use of State Owned in table 6. The results across two subsamples are in general consistent with our main findings that the association between IPO underpricing and SEO timing/size becomes less significant in SOEs as per the construct State Present.

Similar results are shown in table 10, where state ownership is represented by State Major that indicates if the state ownership account for more than half of a firm's total shareholdings. We find that IPO underpricing is significantly related to SEO time in firms with lower state ownership $(<50 \%)$, whereas this link becomes insignificant in firms with higher state ownership (>50\%). On the other hand, although IPO underpricing is positively and significantly connected with SEO size in both subgroups with different levels of state ownership, the negative coefficient pertaining to the interacted term in column (6) reveals the moderating effect of state influence on the connection between IPO and SEO proceeds. Considering the results in tables 9 and 10 together, we argue that one of the channels that government implements its influence on firms is through ownership. More importantly, we suggest that government does not need to hold a large proportion of a firm's share to maintain its influence; the existence of state shares in a firm can affect its behavior towards the preference of the government.

Moreover, we notice that the association between IPO underpricing and SEO performance depend on the state ownership of firms; yet, there could be other factors beyond state ownership affecting this relationship. We, therefore, employ the propensity score matching (PSM) method to generate the most comparable treated (SOE) and controlled firms (non-SOE) and run a regression for the subset of firms. In applying PSM, we first run a probit model using our full sample, where the dependent variable is 1 if the firm is state-owned; 0 , otherwise. The probit model includes all control variables from our main regressions. We use the propensity scores estimated from this probit model to 
perform a matching between SOE and non-SOE firms, following the closest score as proposed by Smith and Todd (2005). The regression results using matched sample are consistent with main results and show that the association between IPO underpricing and SEO time/SEO proceeds is moderated in stateowned firms.

\subsection{Other Sensitivity Tests}

We perform several additional sensitivity tests: $(i)$ using IPOs initial returns by adjusting market indices and firms' industrial median, by using the standard industry codes in the GTA database; (ii) using the number of months (logarithmic values) between IPO and SEO as the measure of SEO time; (iii) adjusting the proceeds of SEOs by incorporating the inflation rate to control the changes in the macroeconomic environment; (iv) winsorising the SEO return, time, and size at the $5^{\text {th }}$ and $95^{\text {th }}$ percentiles to control for outliers; $(v)$ excluding firms with total assets less than 200 million CNY (leaving out 22 firms); (vi) excluding companies that went public between January $1^{\text {st }}$ and July $27^{\text {th }}$ in 1999, since the share offering price during that period was strictly set by the government on the basis of the pre-fixed P/E ratio method; (vii) running regressions for the sub-samples of various SEOs and IPOs allocation mechanisms (i.e., private placement, public offering, right issues and bookbuilding) to weigh the impact of regulatory changes; and (viii) running the regression for the time period between 2005 and 2015 only as the state control was stronger during 1990 to 2004 . None of these considerations changed the implications and quality of our findings. ${ }^{8}$

\section{Conclusion}

This study provides novel evidence on the connection between IPO underpricing and SEO decisions and offer outcomes in relation to Chinese governmental intervention. The unique context of the Chinese institutional setting provides the basis of a natural experiment. It offers the opportunity to examine whether state involvement is beneficial or disadvantageous to the functioning of markets and

\footnotetext{
${ }^{8}$ We report the results for some of the additional analyses mentioned in sections 5.1 and 5.2 in the supplementary materials, and the unreported results are available on request.
} 
their efficiency, and facilitates the information revealed in the Chinese stock markets.

Using a large sample, we provide empirical evidence for the positive connection between IPO immediate aftermarket returns and SEO activities. This supports Jegadeesh et al.'s (1993) statement and confirms that issuers employ high initial returns to benefit their future share issuances in China. More importantly, we document that the promoting effect of underpriced IPOs on SEO issuances becomes weak with the presence of governmental intervention. In particular, we explore the influence of state involvement through three channels in our study, namely state ownership, political connections and specific/strategic location. By dividing the full IPO sample into sub-groups, we examine the role of the governmental authorities in influencing equity financing strategy of Chinese listed firms. We conclude that firms without state involvement tend to consider the strategy of IPO and SEO collectively as a whole progress. They incline to accept underpriced IPOs for a better return from SEOs. On the contrary, underpriced IPOs are more likely to be perceived as a compensation for high uncertainty and severe agency conflicts in firms under governmental intervention.

Our analysis makes important contributions to the area of corporate finance in emerging markets. It offers important insights into our understanding of the mechanism through which firms can elaborate an earlier and larger SEO in the Chinese stock market. Additionally, our study considers IPOs and SEOs collectively and supports the notion that state objectives and intervention affect firms' strategy of raising capital from the equity markets. The findings suggest important implications for government, policy makers, and practitioners. For instance, knowing the association between IPOs and SEOs can help issuers set the equity issuance strategy in the long-term. The positive connection between underpriced IPOs and SEO activities informs Chinese firms strategically about setting their SEO plans for future at the time of IPO, which aims to maximise the capital raised over the life cycle of the corporation. Moreover, the moderating effect of state intervention on the association between IPOs and SEOs suggests governmental interference is a type of friction in Chinese capital markets that drives firms into less optimal equity issuance activities. The Chinese government can consider weakening its influence 
on listed firms not only by reducing the state ownership but also by cutting the connection with executives in industries and softening the investment restrictions in developing areas.

Future research can examine whether $i$ ) the riskiness of IPO firms changes via subsequent SEOs in the medium- to long-term; ii) the link between IPO and SEO outcomes depends on the changes in the real investment, cash holdings and dividend policies; iii) the Chinese managers have any optimal debt ratios in mind before deciding on the SEO issues to rebalance their capital structure; and $i v$ ) alternative measures (see Francis et al., 2009), other than the SOEs status, of political connectedness such as political links of the underwriters and board members would yield different findings.

\section{References}

Allen, F., Qian, J. Qian, M., 2005. Law, finance, and economic growth in China. Journal of Financial Economics 77, 57-116.

Almazan, A., De Motta, A., Titman, S., Uysal, V., 2010. Financial Structure, Acquisition Opportunities, and Firm Locations. The Journal of Finance 65, 529-563.

An, H., Chen, Y., Luo, D., Zhang, T., 2016. Political uncertainty and corporate investment: Evidence from China. Journal of Corporate Finance 36, 174-189.

Bayar, O., Chemmanur, T., Fulghieri, P., 2019. Optimal disclosure and litigation rules around IPOs and SEOs. SSRN Working Paper.

Behr, P., Kisgen, D.J., Taillard, J.P., 2018. Did government regulations lead to inflated credit ratings? Management Science 64, 1034-1054.

Bloom, N., Mahajan, A., McKenzie, D., 2010. Why do firms in developing countries have low productivity? American Economic Review 100, 619-623.

Bo, H., Huang, Z., Wang, C., 2011. Understanding seasoned equity offerings of Chinese firms. Journal of Banking \& Finance 35, 1143-1157.

Bonardo, D., Paleari, S., Vismara, S., 2010. The M\&A dynamics of European science-based entrepreneurial firms. The Journal of Technology Transfer 35, 141-180.

Borisova, G., Brockman, P., Salas, J.M., Zagorchev, A., 2012. Government ownership and corporate governance: Evidence from the EU. Journal of Banking \& Finance 36, 2917-2934.

Borisova, G., Fotak, V., Holland, K., Megginson, W.L., 2015. Government ownership and the cost of debt: Evidence from government investments in publicly traded firms. Journal of Financial Economics 118, 168191.

Borisova, G., Megginson, W.L., 2011. Does Government Ownership Affect the Cost of Debt? Evidence from Privatization. The Review of Financial Studies 24, 2693-2737.

Brennan, M.J., Franks, J., 1997. Underpricing, ownership and control in initial public offerings of equity securities in the UK. Journal of Financial Economics 45, 391-413.

Bruno, V., Cornaggia, J., Cornaggia, K.J., 2016. Does regulatory certification affect the information content of credit ratings? Management Science 62, 1578-1597.

Bruton, G.D., Filatotchev, I., Chahine, S., Wright, M., 2010. Governance, ownership structure and performance of IPO firms: the impact of different types of private equity investors and institutional environments. Strategic Management Journal 31, 491-509.

Bruton, G.D., Peng, M.W., Ahlstrom, D., Stan, C., Xu, K. 2015. State-owned enterprises around the world as hybrid organizations. Academy of Management Perspectives 29, 92-114.

Byeongju, J., 2002. Policy uncertainty and long-run investment and output across countries. International Economic Review 43, 363-392. 
Cao, X., Lemmon, M., Pan, X., Qian, M., Tian, G., 2019. Political Promotion, CEO Incentives, and the Relationship between Pay and Performance. Management Science 65, 2947-2965.

Chan, Y., Saffar, W., Wei, KC., 2017. How economic policy uncertainty affects the cost of raising equity capital: Evidence from seasoned equity offerings. Working Paper.

Chemmanur, TJ., 1993. The pricing of initial public offerings: A dynamic model with information production. Journal of Finance 48, 285-304.

Chen, G., Firth, M., Kim, J.-B., 2004. IPO underpricing in China's new stock markets. Journal of Multinational Financial Management 14, 283-302.

Chen, G., Firth, M., Xin, Y., Xu, L., 2008. Control transfers, privatization, and corporate performance: Efficiency gains in China's listed companies. Journal of Financial and Quantitative Analysis 43, 161-190.

Chen, D., Guan, Y., Zhang, T., Zhao, G., 2017. Political connection of financial intermediaries: evidence from China's IPO market. Journal of Banking \& Finance 76, 15-31.

Chen, Y., Hung, M., Wang, Y., 2018. The effect of mandatory CSR disclosure on firm profitability and social externalities: Evidence from China. Journal of Accounting and Economics 65, 169-190.

Chen, D., Khan, S., Yu, X., Zhang, Z., 2013. Government intervention and investment comovement: Chinese evidence. Journal of Business Finance \& Accounting 40, 564-587.

Chen, C., Shi, H., Xu, H., 2013. Underwriter reputation, issuer ownership, and pre-IPO earnings management: evidence from China. Financial Management 42, 647-677.

Chen, S., Sun, Z., Tang, S., Wu, D., 2011. Government intervention and investment efficiency: evidence from China. Journal of Corporate Finance 17, 259-271.

Chen, K.C.W., Wang, J., 2007. Accounting-based regulation in emerging markets: the case of China's seasonedequity offerings. International Journal of Accounting 42, 221-236.

Chen, Y., Wang, S., Li, W., Sun, Q., Tong, W., 2015. Institutional environment, firm ownership, and IPO firstday returns: Evidence from China. Journal of Corporate Finance 32, 150-168.

Chizema, A., Liu, X., Lu, J., Gao, L., 2015. Politically connected boards and top executive pay in Chinese listed firms. Strategic Management Journal 36, 890-906.

Chowdhry, B., Sherman, A., 1996. International differences in oversubscription and underpricing of IPOs. Journal of Corporate Finance 2, 359-381.

Clinton, S.B., White, J.T., Woidtke, T., 2014. Differences in the information environment prior to seasoned equity offerings under relaxed disclosure regulation. Journal of Accounting and Economics 58, 59-78.

Cohen, B.D., Dean, T.J., 2005. Information asymmetry and investor valuation of IPOs: Top management team legitimacy as a capital market signal. Strategic Management Journal 26, 683-690.

Colombo, M.G., Meoli, M., Vismara, S., 2019. Signaling in science-based IPOs: the combined effect of affiliation with prestigious universities, underwriters, and venture capitalists. Journal of Business Venturing 34, 141-177

Connelly, B.L., Lee, K.B., Tihanyi, L., Certo, S.T., Johnson, J.L., 2019. Something in common competitive dissimilarity and performance of rivals with common shareholders. Academy of Management Journal 62, 121.

Cornelli, F., Goldreich, D., 2003. Bookbuilding: How informative is the order book? Journal of Finance 58, 14151443.

Cornelli, F., Goldreich, D., Ljungqvist, A., 2006. Investor sentiment and pre-IPO markets. Journal of Finance 61, 1187-1216.

Deng, L., Jiang, P., Li, S., Liao, M., 2017. Government intervention and firm investment. Journal of Corporate Finance.

Edmans, A., Goldstein, I., Jiang, W., 2012. The real effects of financial markets: the impact of prices on takeovers. Journal of Finance 67, 933-971.

Faccio, M. 2006. Politically Connected Firms. American Economic Review 96, 369-386.

Fan, J., Wong, T., Zhang, T., 2007. Politically connected CEOs, corporate governance, and post-IPO performance of China's newly partially privatized firms. Journal of Financial Economics 84, 330-357.

Fan, L., Zhang, C., 2007. Beyond segmentation: the case of China's repo markets. Journal of Banking \& Finance 31, 939-954.

Farinós, J.E., García, C.J., Ibáñez, A.M., 2007. Operating and stock market performance of state-owned enterprise privatizations: The Spanish experience. International Review of Financial Analysis 16, 367-389.

Filatotchev, I., 2006. Effects of executive characteristics and venture capital involvement on board composition and share ownership in IPO firms. British Journal of Management 17, 75-92.

Firth, M., Li, W., Shuye Wang, S., 2016. The growth, determinants, and profitability of nontraditional activities 
of Chinese commercial banks. The European Journal of Finance 22, 259-287.

Firth, M., Lin, C., Zou, H., 2010. Friend or foe? The role of state and mutual fund ownership in the split share structure reform in China. Journal of Financial and Quantitative Analysis 45, 685-706.

Francis, B.B., Hasan, I., Lothian, J.R., Sun, X., 2010. The signaling hypothesis revisited: evidence from foreign IPOs. Journal of Financial and Quantitative Analysis 45, 81-106.

Francis, B.B., Hasan, I. and Sun, X., 2009. Political connections and the process of going public: evidence from China. Journal of International Money and Finance 28, 696-719.

Ghosh, C., Nag, R., Sirmans, C.F., 2000. A test of the signaling value of IPO underpricing with REIT IPO-SEO pairs. Journal of Real Estate Finance and Economics 20, 137-154.

Guo, D., Guo, Y., Jiang, K., 2016. Government-subsidized R\&D and firm innovation: evidence from China. Research Policy 45, 1129-1144.

Guo, Y., Huy, Q.N., Xiao, Z., 2017. How middle managers manage the political environment to achieve market goals: Insights from China's state-owned enterprises. Strategic Management Journal, 38, 676-696.

Gul, F.A., Kim, J., Qiu, A.A., 2010. Ownership concentration, foreign shareholding, audit quality, and stock price synchronicity: evidence from China. Journal of Financial Economics 95, 425-442.

Heckman, J.J., 1979. Sample selection bias as a specification error. Econometrica 47, 153-162.

Hill. P., 2006. Ownership structure and IPO underpricing. Journal of Business Finance and Accounting 33, $102-$ 126.

Hou, W., Kuo, J., Lee, E., 2012. The impact of state ownership on share price informativeness: the case of the Split Share Structure Reform in China. British Accounting Review 44, 248-261.

Huang, Y., Uchida, K., Zha, D., 2016. Market timing of seasoned equity offerings with long regulative process. Journal of Corporate Finance 39, 278-294.

Hung, M., Wong, T., Zhang, T., 2012. Political considerations in the decision of Chinese SOEs to list in Hong Kong. Journal of Accounting and Economics 53, 435-449.

Hülsbeck, M., Meoli, M., Vismara, S., 2019. The board value protection function in young, mature and family firms. British Journal of Management 30, 437-458.

Jegadeesh, N., Weinstein, M., Welch, I., 1993. An empirical investigation of IPO returns and subsequent equity offerings. Journal of Financial Economics 34, 153-175.

Jia, N., Huang, K.G. and Man Zhang, C., 2019. Public governance, corporate governance, and firm innovation: an examination of state-owned enterprises. Academy of Management Journal, 62(1), 220-247.

Jones, S.L., Megginson, W.L., Nash, R.C., Netter, J.M., 1999. Share issue privatizations as financial means to political and economic ends. Journal of Financial Economics 53, 217-253.

John, K., Knyazeva, A., Knyazeva, D., 2011. Does geography matter? Firm location and corporate payout policy. Journal of Financial Economics 101, 533-551.

Kotlar, J., Signori, A., De, Massis A., Vismara, S., 2018. Financial wealth, socioemotional wealth, and IPO underpricing in family firms: a two-stage gamble model. Academy of Management Journal 61, 1073-1099.

Kroll., M., Walters, B.A., A., S., 2007. The impact of board composition and top management team ownership structure on post IPO performance in young entrepreneurial firms. Academy of Management Journal 50, 11981216.

La Porta, R., Lopez-De-Silanes, F., Shleifer, A., 2002. Government Ownership of Banks. Journal of Finance 57, 265-301.

Lazzarini, S.G. 2015. Strategizing by the government: Can industrial policy create firm-level competitive advantage? Strategic Management Journal 36, 97-112.

Latham S., Braun MR., 2010. To IPO or not to IPO: risks, uncertainty and the decision to go public. British Journal of Management 21, 666-83.

Lee, P.J., Taylor, S.L., Walter, T.S., 1996. Australian IPO pricing in the short and long run. Journal of Banking and Finance 20,1189-1210.

Li, J., Qian, C., 2013. Principal-principal conflicts under weak institutions: a study of corporate takeovers in China. Strategic Management Journal 34, 498-508.

Li, J., Tang, Y., 2010. CEO hubris and firm risk taking in China: the moderating role of managerial discretion. Academy of Management Journal 53, 45-68.

Li, J., Li, P., Wang, B., 2019. The liability of opaqueness: State ownership and the likelihood of deal completion in international acquisitions by Chinese firms. Strategic Management Journal 40, 303-327.

Li, W., Zhang, R., 2010. Corporate Social Responsibility, Ownership Structure, and Political Interference: Evidence from China. Journal of Business Ethics 96, 631-645. 
Lichtenberg, F. R., Siegel, D., 1990. The effects of leveraged buyouts on productivity and related aspects on firms' behaviour. Journal of Financial Economics 27, 165-194.

Liu, X., Ritter, J., 2011. Local underwriter oligopolies and IPO underpricing. Journal of Financial Econonics 102, 579-601.

Liu, Z., Wu, H., Wu, J., 2019. Location-based tax incentives and entrepreneurial activities: evidence from Western Regional Development Strategy in China. Small Business Economics 52, 729-742.

Loughran, T., Ritter, J.R., 1995. The new issues puzzle. Journal of Finance 50, $23-51$.

Lowry, M., Shu, S., 2002. Litigation risk and IPO underpricing. Journal of Financial Economics 65, 309-335.

Lungeanu, R., Zajac, E.J., 2016. Venture capital ownership as a contingent resource: how owner firm fit influence IPO outcomes. Academy of Management Journal 59, 930-955.

McGuinness, P.B., 2018. Beyond the board realm: women in senior management and their impact on IPO capital funding. British Journal of Management 30, 389-414.

Meoli, M., Paleari, S., Vismara, S., 2013. Completing the technology transfer process: M\&As of science-based IPOs. Small Business Economics, 40, 227-248.

Newey, W., 1987. Efficient estimation of limited dependent variable models with endogenous explanatory variables. Journal of Econometrics 36, 231-250.

Nielsson, U., Wójcik, D., 2016. Proximity and IPO underpricing. Journal of Corporate Finance 38, 92-105.

Pan, Y., Chi, P.S., 1999. Financial performance and survival of multinational corporations in China. Strategic Management Journal 20, 359-374

Park, U. D., Borah, A., \& Kotha, S. 2016. Signaling revisited: the use of signals in the market for IPOs. Strategic Management Journal, 37: 2362-2377.

Park, H. D., \& Patel, P. C. 2015. How Does Ambiguity Influence IPO Underpricing? The Role of the Signalling Environment. Journal of Management Studies, 52(6): 796-818.

Piotroski, JD., Zhang, T., 2014. Politicians and the IPO decision: the impact of impending political promotions on IPO activity in China. Journal of Financial Economics 21, 111-36.

Ragozzino, R., Reuer, J.J., 2011. Geographic distance and corporate acquisitions: Signals from IPO firms. Strategic Management Journal 32, 876-894.

Ravenscraft, D., Scherer, F.M., 1988. Mergers, sell-offs, and economic efficiency. Journal of Economic Behavior and Organization 10, 368-372.

Rodrik, D., 1991. Policy uncertainty and private investment in developing countries. Journal of Development Economics 36, 229-242.

Sapienza, P., 2004. The effects of government ownership on bank lending. Journal of Financial Economics 72, 357-384.

Shao, Y., Hernández, R., Liu, P., 2015. Government intervention and corporate policies: Evidence from China. Journal of Business Research 68, 1205-1215.

Shleifer, A., Vishny, R., 1994. Politicians and firms. Quarterly Journal of Economics 109, 995-1025.

Smith, J.A., Todd, P.E., 2005. Does matching overcome LaLonde's critique of nonexperimental estimators? Journal of Econometrics 125, 305-353.

Slovin, M.B., Sushka, M.E., Bendeck, Y.M., 1994. Seasoned common stock issuance following an IPO. Journal of Banking and Finance 18, 207-226.

Spiess, D.K., Pettway, R.H., 1997. The IPO and first seasoned equity sale: Issue proceeds, owner/managers' wealth, and the underpricing signal. Journal of Banking and Finance 21, 967-988.

Sun, Q., Tong, W.H.S., Tong, J., 2002. How Does Government Ownership Affect Firm Performance? Evidence from China's Privatization Experience. Journal of Business Finance \& Accounting 29, 1-27.

Tenev S, Zhang C. 2002. Corporate Governance and Enterprise Reform in China. World Bank: Washington, DC.

Tian, L. 2011. Regulatory underpricing: determinants of Chinese extreme IPO returns. Journal of Empirical Finance 18, 78-90.

Thomadakis, S., Gounopoulos, D., Nounis, C., Merikas, A., 2016. Collateral regulation and IPO-specific liberalisation: the case of price limits in the Athens stock exchange. European Financial Management 22, 276312.

Thomsen, S., Pedersen, T., 2000. Ownership structure and economic performance in the largest European companies. Strategic Management Journal 21, 689-705.

Vithanage, K., Neupane, S., Chung, R., 2016. Multiple lead underwriting syndicate and IPO pricing. International Review of Financial Analysis 48, 193-208.

Welch, I., 1989. Seasoned offerings, imitation costs, and the underpricing of initial public offerings. Journal of 
Finance 44, 421-449.

Xia, F., Walker, G., 2015. How much does owner type matter for firm performance? Manufacturing firms in China 1998-2007. Strategic Management Journal, 36, 576-585.

Xu, N., Li, X., Yuan, Q., Chan, K.C., 2014. Excess perks and stock price crash risk: evidence from China. Journal of Corporate Finance 25, 419-434.

Yu, T., Tse, Y.K., 2006. An empirical examination of IPO underpricing in the Chinese A-share market. China Economic Review 17, 363-382.

Yuan, R., Xiao, JZ., Milonas, N., Zou, JH., 2009. The role of financial institutions in the corporate governance of listed Chinese companies. British Journal of Management 20, 562-580.

Zheng, W., Ni, N., Crilly, D., 2019. Non-profit organizations as a nexus between government and business: Evidence from Chinese charities. Strategic Management Journal 40, 658-684. 


\section{Appendix}

\section{Table A1. The definition of the variable}

\section{Panel A: Dependent variables}

SEO Time

SEO Relative Size

SEO Time (in month)

Panel B: IPO characteristics

IPO Underpricing

Shanghai

Abnormal return_1

Abnormal return_2

Market Momentum

\section{Panel C: SEO characteristics}

Underwriter Reputation_SEO

SEO Leverage

Market_to_Book

Board Size

Board Independence

CEO Ownership

Ownership Concentration

Panel D: Governmental intervention

Political Connection

Location

State Present

State Major

Panel E: Instrumental variables

IPO Oversubscription

Panel F: Robustness tests

IPO Size

Firm Age_IPO

TPO Leve Lag

IPO Leverage
Dummy variable: 1 if the firm did its first SEO within 3 years after IPO; otherwise, 0

The ratio of proceeds raised by the first SEO divided by proceeds raised during IPO. It is equal to 0 if the firm does not issue any SEO.

The natural logarithm of the number of months between the IPO and SEO issuances.

Initial return on the IPO, which is calculated as the difference between closing share price of first day of IPO and issue share price of IPO divided by issue share price. Dummy variable: 1 if the firm is listed in Shanghai stock market; otherwise, 0.

Abnormal return during trading days 1 to 20 after the IPO date. The abnormal return is estimated as stock return minus beta times the market return. Chinese A-share value weighted index is used as the market proxy and beta is estimated from a market-model regression fitted over days 1 to 20 following the IPO date.

Abnormal return over the period from trading days 21 to 40 after the IPO date.

Dummy variable: 1 when the trading volume in the specific IPO month is above the median trading volume of the most recent three months; otherwise, 0 . Further, we look at the number of IPOs performed during the quarter on a comparative basis.

Dummy variable: 1 if the firm had an SEO with a lead advisor among top 10 Chinese underwriters; otherwise, 0.

Total debt divided by total equity prior to the first SEO.

Market value of equity less book value of equity plus total assets, scaled by total assets prior to the first SEO.

The number of people in the corporate board prior to the first SEO.

The percentage of independent directors on a board prior to the first SEO.

The percentage of shares held by the CEO of the company prior the first SEO.

The percentage of shares held by the top three shareholders.

Dummy variable: 1 if a firm is state-owned, otherwise 0 . We define an entity as state-owned if the state i) can decide the election of more than half directors on board via exercising it voting rights or ii) holds more than $30 \%$ of a company's shareholdings or voting rights or iii) can exercise voting rights more than the largest shareholder of the firm or iv) is the largest shareholder of the firm.

Dummy variable: 1 if a firm is politically connected, otherwise, 0 . We define political connectedness if the CEO or Chairperson of the firm currently holds or previously held a position in one or several organisations, including central or local government, national or local People's Congress, Chinese People's Political Consultative Conference (Faccio, 2006; Li and Zhang, 2010).

Dummy variable: 1 if the firm's headquarter is located within the economic development areas (i.e., Shanghai, Beijing, Chongqing, Shenzhen, Guangzhou, Tianjin, Wuhan, Dongguan, Shenyang, Hangzhou and Nanjing), otherwise, 0 (Shao et al., 2015; An et al., 2016).

Dummy variable: 1 if a firm's state ownership of its stocks is non-zero; otherwise, 0.

Dummy variable: 1 if the state ownership of the firm's stocks is more than $50 \%$ of the total shareholdings; otherwise, 0 .

The natural logarithm of the ratio of the number of shares requested to the number of shares issued.

Dummy variable: 1 if the firm carried its IPO through one of the top 10 Chinese underwriters; otherwise, 0.

The natural logarithm of total number of shares multiplied by IPO share price.

The natural logarithm of the number of days between the IPO date and the firm's establishment date.

The natural logarithm of the number of days between the IPO announcement and listing dates.

Total debt divided by total equity on the IPO date. 
Table A2. Correlation matrix

This table reports the correlation coefficients among the variables. $*(* *)(* * *)$ indicates that the coefficient is significant at the $10 \%(5 \%)(1 \%)$ level, respectively.

\begin{tabular}{|c|c|c|c|c|c|c|c|c|c|c|c|c|c|c|c|c|c|}
\hline & (1) & (2) & (3) & (4) & (5) & (6) & (7) & (8) & (9) & (10) & (11) & (12) & (13) & (14) & (15) & (16) & (17) \\
\hline SEO Time (1) & 1.000 & & & & & & & & & & & & & & & & \\
\hline SEO Relative Size (2) & $0.207 * * *$ & & & & & & & & & & & & & & & & \\
\hline IPO Oversubscription (3) & $0.100 * * *$ & $0.238^{* * *}$ & & & & & & & & & & & & & & & \\
\hline IPO Underpricing (4) & $0.268 * * *$ & $0.458^{* * *}$ & $0.414 * * *$ & & & & & & & & & & & & & & \\
\hline State Owned (5) & $0.300 * * *$ & $0.163 * * *$ & $0.104 * *$ & $0.282 * * *$ & & & & & & & & & & & & & \\
\hline Political Connection (6) & 0.082 & 0.062 & $0.163 * * *$ & $0.374 * * *$ & $0.232 * * *$ & & & & & & & & & & & & \\
\hline Location (7) & -0.032 & -0.052 & 0.018 & -0.014 & 0.0026 & -0.0283 & & & & & & & & & & & \\
\hline Shanghai (8) & $0.190 * * *$ & 0.063 & 0.112 & $0.162 * * *$ & $0.340 * * *$ & $0.220 * * *$ & 0.023 & & & & & & & & & & \\
\hline Abnormal return_1 (9) & 0.004 & 0.006 & 0.02 & -0.0814 & -0.02 & -0.011 & 0.002 & -0.002 & & & & & & & & & \\
\hline Abnormal return 2 (10) & $0.086 *$ & 0.058 & 0.000 & -0.031 & 0.059 & -0.004 & -0.023 & 0.005 & -0.049 & & & & & & & & \\
\hline Market Momentum (11) & -0.111 & -0.076 & -0.016 & -0.067 & -0.067 & -0.038 & 0.023 & -0.078 & -0.067 & -0.0967 & & & & & & & \\
\hline SEO Leverage (12) & -0.1583 & $0.153 * *$ & 0.059 & 0.040 & 0.029 & -0.002 & -0.006 & -0.046 & -0.045 & 0.003 & 0.018 & & & & & & \\
\hline Market_to_Book (13) & -0.024 & 0.059 & 0.020 & 0.037 & -0.050 & -0.045 & 0.101 & 0.006 & -0.008 & 0.054 & 0.037 & $-0.204 * * *$ & & & & & \\
\hline Underwriter Reputation SEO (14) & -0.030 & -0.032 & -0.087 & -0.081 & 0.045 & -0.073 & 0.035 & -0.095 & 0.036 & 0.042 & -0.023 & 0.008 & 0.019 & & & & \\
\hline Board Independence $(1 \overline{5})$ & -0.631 & $0.121 *$ & $0.193 * * *$ & $-0.203 * * *$ & $-0.433 * * *$ & $-0.192 * * *$ & -0.046 & $-0.386 * * *$ & 0.044 & -0.039 & 0.057 & 0.172 & -0.015 & 0.025 & & & \\
\hline CEO Ownership (16) & $-0.161 * * *$ & -0.029 & 0.032 & $-0.123 *$ & $-0.353^{* * *}$ & $-0.138 * *$ & -0.003 & $-0.235 * * *$ & 0.024 & 0.011 & 0.033 & -0.029 & 0.088 & 0.044 & 0.411 & & \\
\hline Ownership Concentration (17) & -0.094 & 0.052 & 0.022 & -0.099 & -0.039 & -0.050 & 0.089 & -0.063 & 0.078 & -0.016 & -0.001 & 0.001 & 0.112 & $0.136 * *$ & $0.124 *$ & 0.116 & \\
\hline Board Size (18) & 0.116 & 0.060 & -0.024 & 0.041 & $0.217 * * *$ & 0.054 & 0.018 & $0.127 *$ & 0.039 & -0.001 & -0.056 & 0.016 & -0.079 & 0.002 & $-0.197 * * *$ & $-0.126^{*}$ & -0.073 \\
\hline
\end{tabular}


Table 1. Descriptive statistics.

This table presents descriptive statistics for a sample of Chinese IPOs and SEOs over the period between 1990 and 2015. Panels A and B present the statistics of all firms in our sample, and companies having conducted their first SEOs, respectively. Firms that conducted IPOs after 2012 are excluded from our sample because it is unknown whether they would accomplish their first SEOs within three years of IPOs. IPO Oversubscription shows the values without the logarithmic transformation. All variables are defined in the Appendix.

\begin{tabular}{|c|c|c|c|c|c|c|}
\hline Variables & $\mathrm{N}$ & Mean & Std. dev. & Min & Med & Max \\
\hline \multicolumn{7}{|l|}{ Panel A: 1708 IPOs } \\
\hline IPO Underpricing & 1708 & 0.980 & 1.090 & -0.214 & 0.658 & 9.381 \\
\hline State Owned & 1708 & 0.367 & 0.482 & 0.000 & 0.000 & 1.000 \\
\hline Political Connection & 1708 & 0.359 & 0.480 & 0.000 & 0.000 & 1.000 \\
\hline Location & 1708 & 0.364 & 0.481 & 0.000 & 0.000 & 1.000 \\
\hline Shanghai & 1708 & 0.297 & 0.457 & 0.000 & 0.000 & 1.000 \\
\hline Abnormal return_1 & 1708 & -0.001 & 0.124 & -0.449 & -0.011 & 0.746 \\
\hline Abnormal return_2 & 1708 & 0.002 & 0.114 & -0.393 & -0.003 & 0.651 \\
\hline Market Momentum & 1708 & 0.526 & 0.499 & 0.000 & 1.000 & 1.000 \\
\hline IPO Oversubscription & 1708 & 274.036 & 283.531 & 1.104 & 173.217 & 1126.144 \\
\hline SEO Time & 1708 & 0.263 & 0.441 & 0.000 & 0.000 & 1.000 \\
\hline SEO Relative Size & 1708 & 0.720 & 1.470 & 0.000 & 0.000 & 16.651 \\
\hline \multicolumn{7}{|l|}{ Panel B: 804 with SEOs } \\
\hline IPO Underpricing & 804 & 1.350 & 1.223 & -0.214 & 1.079 & 9.381 \\
\hline State Owned & 804 & 0.512 & 0.500 & 0.000 & 1.000 & 1.000 \\
\hline Political Connection & 804 & 0.403 & 0.491 & 0.000 & 1.000 & 1.000 \\
\hline Location & 804 & 0.330 & 0.470 & 0.000 & 1.000 & 1.000 \\
\hline Shanghai & 804 & 0.353 & 0.478 & 0.000 & 0.000 & 1.000 \\
\hline Abnormal return_1 & 804 & -0.001 & 0.133 & -0.449 & -0.011 & 0.746 \\
\hline Abnormal return_2 & 804 & 0.016 & 0.121 & -0.350 & 0.008 & 0.651 \\
\hline Market Momentum & 804 & 0.437 & 0.496 & 0.000 & 0.000 & 1.000 \\
\hline IPO Oversubscription & 804 & 331.612 & 296.742 & 1.104 & 240.558 & 1126.144 \\
\hline SEO Leverage & 804 & 1.009 & 1.284 & 0.024 & 0.764 & 23.581 \\
\hline Market_to_Book & 804 & 2.471 & 1.553 & 0.263 & 2.133 & 16.829 \\
\hline Underwriter Reputation_SEO & 804 & 0.379 & 0.485 & 0.000 & 0.000 & 0.571 \\
\hline Board Size & 804 & 9.220 & 2.273 & 3.000 & 9.000 & 19.000 \\
\hline Board Independence & 804 & 0.167 & 0.184 & 0.000 & 0.000 & 0.571 \\
\hline CEO Ownership & 804 & 0.034 & 0.095 & 0.000 & 0.000 & 0.625 \\
\hline Ownership Concentration & 804 & 58.805 & 11.584 & 4.040 & 59.850 & 85.898 \\
\hline SEO Time & 804 & 0.560 & 0.497 & 0.000 & 1.000 & 1.000 \\
\hline SEO Relative Size & 804 & 1.443 & 1.644 & 0.037 & 0.969 & 16.651 \\
\hline
\end{tabular}


Table 2. Breakdown of IPOs and SEOs.

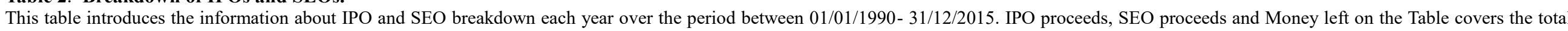

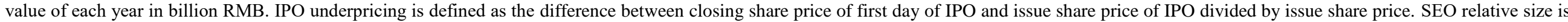

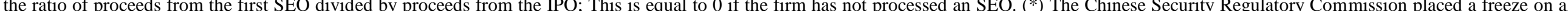
Chinese IPOs from 11/2012 to 12/2013.

\begin{tabular}{|c|c|c|c|c|c|c|c|}
\hline Year & Number of IPOs & IPO Proceeds (¥b) & Money on the Table (¥b) & Mean IPO underpricing & Number of SEOs & SEO Proceeds (¥b) & Mean SEO relative size \\
\hline 1990 & 4 & 0.148 & 0.251 & 2.662 & 0 & 0 & - \\
\hline 1991 & 0 & 0 & 0 & - & 0 & 0 & - \\
\hline 1992 & 12 & 1.441 & 1.330 & 6.496 & 1 & 0.600 & 0.545 \\
\hline 1993 & 63 & 1.886 & 2.564 & 2.367 & 31 & 40.940 & 0.451 \\
\hline 1994 & 62 & 2.531 & 4.557 & 1.423 & 14 & 16.246 & 0.553 \\
\hline 1995 & 16 & 8.062 & 7.605 & 5.070 & 34 & 27.813 & 0.790 \\
\hline 1996 & 134 & 11.276 & 8.403 & 2.349 & 22 & 30.310 & 0.491 \\
\hline 1997 & 163 & 11.727 & 9.262 & 1.912 & 40 & 56.929 & 1.108 \\
\hline 1998 & 66 & 16.494 & 10.026 & 1.909 & 101 & 211.514 & 1.881 \\
\hline 1999 & 54 & 19.096 & 11.935 & 0.989 & 74 & 159.834 & 1.462 \\
\hline 2000 & 73 & 23.580 & 13.708 & 1.568 & 83 & 228.682 & 1.357 \\
\hline 2001 & 32 & 24.382 & 15.284 & 1.444 & 46 & 157.096 & 1.398 \\
\hline 2002 & 25 & 26.301 & 17.677 & 1.801 & 7 & 19.430 & 0.558 \\
\hline 2003 & 20 & 29.638 & 18.787 & 0.746 & 7 & 19.430 & 0.558 \\
\hline 2004 & 59 & 32.431 & 21.903 & 0.740 & 12 & 119.115 & 1.659 \\
\hline 2005 & 8 & 38.318 & 22.122 & 0.502 & 3 & 12.106 & 0.716 \\
\hline 2006 & 40 & 45.968 & 27.845 & 0.901 & 9 & 40.713 & 1.854 \\
\hline 2007 & 84 & 53.833 & 28.523 & 1.954 & 25 & 307.780 & 1.732 \\
\hline 2008 & 61 & 69.463 & 32.229 & 1.162 & 17 & 130.926 & 2.085 \\
\hline 2009 & 74 & 69.712 & 42.245 & 0.729 & 21 & 154.545 & 1.511 \\
\hline 2010 & 295 & 72.946 & 45.779 & 0.408 & 36 & 364.888 & 1.816 \\
\hline 2011 & 236 & 80.126 & 52.775 & 0.197 & 43 & 301.332 & 1.935 \\
\hline 2012 & 127 & 225.204 & 67.985 & 0.214 & 16 & 104.606 & 1.622 \\
\hline $2013^{*}$ & 0 & 0.000 & 0.000 & - & 49 & 308.242 & 1.390 \\
\hline 2014 & 106 & 234.993 & 102.935 & 0.434 & 53 & 475.138 & 1.631 \\
\hline 2015 & 37 & 324.494 & 297.294 & 0.440 & 60 & 512.599 & 1.458 \\
\hline Total/average & 1,851 & 1424.049 & 863.024 & 1.555 & 804 & 3800.815 & 1.273 \\
\hline
\end{tabular}


Table 3. IPO characteristics between firms with and without SEO

Panel A compares the mean and median values of IPO characteristics between firms with and without SEO. Firms are classified as 'with SEO' if they issue an SEO within 3 years of their IPO. Firms are classified as 'without SEO' if they have not issued an SEO or they issue an SEO after three years of their IPO. Panel B compares SEOs characteristics between underpriced and overpriced IPOs. An IPO is underpriced if the firm's IPO offer price is lower than its market price at the end of its first day of trading. Otherwise, an IPO is overpriced. All variables are defined in the Appendix.

\begin{tabular}{|c|c|c|c|c|c|c|}
\hline \multirow{2}{*}{ IPO characteristics } & \multicolumn{2}{|c|}{ With SEOs (1) N=450 } & \multicolumn{2}{|c|}{ Without SEOs (2) N=1258 } & \multicolumn{2}{|c|}{ Difference: $(1)-(2)$} \\
\hline & Mean & Median & Mean & Median & Mean (p-value) & Median (p-value) \\
\hline IPO Underpricing & $146.76 \%$ & $114.61 \%$ & $80.56 \%$ & $47.82 \%$ & $(0.00)$ & $(0.00)$ \\
\hline State Owned & $60.89 \%$ & $100.00 \%$ & $28.06 \%$ & $0.00 \%$ & $(0.00)$ & $(0.00)$ \\
\hline Political Connection & $42.44 \%$ & $0.00 \%$ & $33.55 \%$ & $0.00 \%$ & $(0.00)$ & $(0.00)$ \\
\hline Location & $37.28 \%$ & $0.00 \%$ & $33.78 \%$ & $0.00 \%$ & $(0.18)$ & $(0.20)$ \\
\hline Shanghai & $44.22 \%$ & $0.00 \%$ & $24.56 \%$ & $0.00 \%$ & $(0.00)$ & $(0.00)$ \\
\hline Abnormal Return_1 & $-0.05 \%$ & $-1.16 \%$ & $-0.16 \%$ & $-1.06 \%$ & $(0.87)$ & $(0.03)$ \\
\hline Abnormal Return_2 & $1.88 \%$ & $0.98 \%$ & $-0.34 \%$ & $-0.74 \%$ & $(0.00)$ & $(0.00)$ \\
\hline Market momentum & $43.33 \%$ & $0.00 \%$ & $56.96 \%$ & $100.00 \%$ & $(0.00)$ & $(0.00)$ \\
\hline \multicolumn{7}{|c|}{ Panel B: Underpriced/Overpriced IPOs } \\
\hline & \multicolumn{2}{|c|}{ Underpriced IPOs (1) N=1561 } & \multicolumn{2}{|c|}{ Overpriced IPOs (2) N=147 } & \multicolumn{2}{|c|}{ Difference: (1)-(2) } \\
\hline SEO characteristics & Mean & Median & Mean & Median & Mean (p-value) & Median ( $p$-value) \\
\hline SEO Time & $27.35 \%$ & $0.00 \%$ & $15.64 \%$ & $0.00 \%$ & $(0.00)$ & $(0.00)$ \\
\hline SEO Relative Size & 1.47 & 0.97 & 0.76 & 0.53 & $(0.00)$ & $(0.00)$ \\
\hline \multicolumn{7}{|l|}{ IPO characteristics } \\
\hline IPO Oversubscription & 288.09 & 185.79 & 124.82 & 59.24 & $(0.00)$ & $(0.00)$ \\
\hline
\end{tabular}


Table 4. The effect of IPO underpricing on first SEO issuance.

The table reports regression results exploring the impact of IPO underpricing and other control variables on SEO Time and SEO Relative Size for a sample of Chinese firms over the period 1990 to 2015. SEO Time equals 1 if the firm issue SEO within 3 years after IPO; otherwise, 0. SEO Relative Size is the ratio of proceeds from the first SEO divided by proceeds from the IPO All variables are defined in the Appendix. Three estimation procedures are used: Logit/Tobit estimation (column 1), MLE (column 2) and 2SLS-IV approach (columns $3)$. The standard errors reported in the parentheses are adjusted for heteroscedasticity. The results control for the year and industry effects. $*(* *)(* * *)$ indicates that the coefficient is significant at the $10 \%(5 \%)(1 \%)$ level, respectively.

\begin{tabular}{|c|c|c|c|c|c|}
\hline \multirow[b]{3}{*}{ Dependent Variable } & \multirow{3}{*}{$\begin{array}{l}\text { (1) Logit } \\
\text { SEO Time }\end{array}$} & \multicolumn{2}{|c|}{ (2) MLE } & \multicolumn{2}{|c|}{ (3) IV } \\
\hline & & $1^{\text {st }}$ Stage & $2^{\text {nd }}$ Stage & $1^{\text {st }}$ Stage & $2^{\text {nd }}$ Stage \\
\hline & & IPO Underpricing & SEO Time & IPO Underpricing & SEO Time \\
\hline \multirow[t]{2}{*}{ IPO Underpricing } & $0.489 * * *$ & & $0.534 * * *$ & & $0.262 * * *$ \\
\hline & $(0.052)$ & & $(0.060)$ & & $(0.077)$ \\
\hline \multirow[t]{2}{*}{ Shanghai } & $0.736^{* * *}$ & $0.257 * * *$ & $0.801 * * *$ & $0.307 * *$ & $0.456 * * *$ \\
\hline & $(0.121)$ & $(0.048)$ & $(0.134)$ & $(0.052)$ & $(0.078)$ \\
\hline \multirow[t]{2}{*}{ Abnormal return_1 } & 0.529 & $-0.766 * * *$ & 0.530 & $-0.969 * * *$ & 0.267 \\
\hline & $(0.467)$ & $(0.167)$ & $(0.506)$ & $(0.190)$ & $(0.280)$ \\
\hline \multirow[t]{2}{*}{ Abnormal return_2 } & $1.963 * * *$ & $-0.365 * *$ & $2.150 * * *$ & $-0.424 * *$ & $1.132 * * *$ \\
\hline & $(0.512)$ & $(0.182)$ & $(0.559)$ & $(0.207)$ & $(0.300)$ \\
\hline \multirow[t]{2}{*}{ Market Momentum } & $-0.398 * * *$ & $-0.132 * * *$ & $-0.439 * * *$ & $-0.126 * * *$ & $-0.237 * * *$ \\
\hline & $(0.118)$ & $(0.045)$ & $(0.135)$ & $(0.048)$ & $(0.069)$ \\
\hline \multirow[t]{2}{*}{ IPO Oversubscription } & & $0.365 * * *$ & & $0.372 * * *$ & \\
\hline & & $(0.019)$ & & $(0.020)$ & \\
\hline \multirow[t]{2}{*}{ Constant } & $-2.081 * * *$ & $-0.929 * * *$ & $-2.178 * * *$ & $0.857 * * *$ & $-1.224 * * *$ \\
\hline & $(0.268)$ & $(0.102)$ & $(0.000)$ & $(0.141)$ & $(0.169)$ \\
\hline Industry \&Year & Yes & Yes & Yes & Yes & Yes \\
\hline Observations & 1708 & 1708 & 1708 & 1708 & 1708 \\
\hline LR $\mathrm{Chi}^{2} /$ Wald $\mathrm{Chi}^{2}$ & $184.17 * * *$ & & $55.09 * * *$ & & $104.04 * * *$ \\
\hline (Pseudo) Adj_R ${ }^{2}$ & 0.129 & & & 0.207 & \\
\hline Hausman test & & & & $15.62 * * *$ & \\
\hline
\end{tabular}

Panel B: Determinants of SEO Relative Size

(1) Tobit

(2) MLE

(3) IV

\begin{tabular}{|c|c|c|c|c|c|}
\hline \multirow[b]{2}{*}{ Dependent Variable } & \multirow[b]{2}{*}{ SEO Relative Size } & & \\
\hline & & $\begin{array}{c}1^{\text {st }} \text { Stage } \\
\text { IPO Underpricing }\end{array}$ & $\begin{array}{c}2^{\text {nd }} \text { Stage } \\
\text { SEO Relative Size }\end{array}$ & $\begin{array}{c}1^{\text {st }} \text { Stage } \\
\text { IPO Underpricing }\end{array}$ & $\begin{array}{c}2^{\text {nd }} \text { Stage } \\
\text { SEO Relative Size }\end{array}$ \\
\hline IPO Underpricing & $\begin{array}{c}1.012 * * * \\
(0.054)\end{array}$ & & $\begin{array}{c}0.780 * * * \\
(0.070)\end{array}$ & & $\begin{array}{c}1.431 * * * \\
(0.136)\end{array}$ \\
\hline Shanghai & $\begin{array}{c}0.173 \\
(0.129)\end{array}$ & $\begin{array}{c}0.257 * * * \\
(0.048)\end{array}$ & $\begin{array}{l}-0.102 \\
(0.069)\end{array}$ & $\begin{array}{l}0.307 * * \\
(0.052)\end{array}$ & $\begin{array}{c}0.001 \\
(0.141)\end{array}$ \\
\hline Abnormal return_1 & $\begin{array}{l}0.942 * * \\
(0.474)\end{array}$ & $\begin{array}{c}-0.365 * * \\
(0.182)\end{array}$ & $\begin{array}{l}0.591 * * \\
(0.230)\end{array}$ & $\begin{array}{c}-0.969 * * * \\
(0.190)\end{array}$ & $\begin{array}{c}1.333 * * * \\
(0.496)\end{array}$ \\
\hline Abnormal return_2 & $\begin{array}{c}2.494 * * * \\
(0.519)\end{array}$ & $\begin{array}{c}-0.766 * * * \\
(0.167)\end{array}$ & $\begin{array}{c}0.886^{* * * *} \\
(0.246)\end{array}$ & $\begin{array}{c}-0.424 * * \\
(0.207)\end{array}$ & $\begin{array}{c}2.681 * * * \\
(0.531)\end{array}$ \\
\hline Market Momentum & $\begin{array}{c}-0.469 * * * \\
(0.121)\end{array}$ & $\begin{array}{c}-0.132 * * * \\
(0.045)\end{array}$ & $\begin{array}{l}-0.083 \\
(0.061)\end{array}$ & $\begin{array}{c}-0.126^{* * *} \\
(0.048)\end{array}$ & $\begin{array}{c}-0.408^{* * *} \\
(0.124)\end{array}$ \\
\hline IPO Oversubscription & & $\begin{array}{c}0.365 * * * \\
(0.019)\end{array}$ & & $\begin{array}{c}0.372 * * * \\
(0.020)\end{array}$ & \\
\hline Constant & $\begin{array}{c}-1.497 * * * \\
(0.274)\end{array}$ & $\begin{array}{c}-0.929 * * * \\
(0.102)\end{array}$ & $\begin{array}{c}0.008 \\
(0.079)\end{array}$ & $\begin{array}{c}0.857 * * * \\
(0.141)\end{array}$ & $\begin{array}{l}-1.886^{* * *} \\
(0.302)\end{array}$ \\
\hline Industry \& Year & Yes & Yes & Yes & Yes & Yes \\
\hline Observations & 1708 & 1708 & 1708 & 1708 & 1708 \\
\hline LR Chi ${ }^{2}$ Wald $\mathrm{Chi}^{2}$ & $397.04 * * *$ & & $113.16^{* * *}$ & & $169.88 * * *$ \\
\hline $\begin{array}{l}\text { (Pseudo) Adj_R }{ }^{2} \\
\text { Hausman test }\end{array}$ & 0.081 & & & $\begin{array}{c}0.207 \\
16.11^{* * *}\end{array}$ & \\
\hline
\end{tabular}


Table 5. The Sources of SEO Relative Size: Heckman Procedure.

Using the sample of Chinese firms over the period 1990 to 2015, this table reports the determinants of SEO Relative Size, including IPO underpricing, SEO characteristics and corporate governance. Model (1) presents the OLS results, which includes firms with SEO issuance only. Model (2) presents the results of 2SLS-IV estimation. Model (3) presents the estimation results of Heckman two-stage procedure to address the sample selection bias. IPO Underpricing, Shanghai, Abnormal return_1, Abnormal return_2 and Market Momentum are used to specify the selection equation in which SEO Time is the dependent variable. The dependent variable in the outcome equation is SEO Relative Size, which is the ratio of proceeds from the first SEO divided by proceeds from the IPO. Inverse Mill's ratio is generated via the logit model to detect the presence of self-selection bias, which is then passed into the outcome equation. All variables are defined in the Appendix. The standard errors reported in the parentheses are adjusted for heteroscedasticity. The results control for the year and industry effects. ${ }^{*}(*)(* * *)$ indicates that the coefficient is significant at the $10 \%(5 \%)(1 \%)$ level, respectively.

\begin{tabular}{|c|c|c|c|c|}
\hline \multirow{3}{*}{ IPO Underpricing } & \multirow{2}{*}{$\begin{array}{c}\text { (1) OLS } \\
\text { SEO Relative Size }\end{array}$} & \multicolumn{2}{|c|}{ (2) IV } & \multirow{2}{*}{$\begin{array}{c}\text { (3) Heckman } \\
\text { SEO Relative Size }\end{array}$} \\
\hline & & $\begin{array}{c}1^{\text {st }} \text { Stage } \\
\text { IPO Underpricing }\end{array}$ & $\begin{array}{c}2^{\text {nd }} \text { Stage } \\
\text { SEO Relative Size }\end{array}$ & \\
\hline & $\begin{array}{c}0.548 * * * \\
(0.045)\end{array}$ & & $\begin{array}{c}0.354 * * * \\
(0.116)\end{array}$ & $\begin{array}{c}0.505 * * * \\
(0.052)\end{array}$ \\
\hline Shanghai & $\begin{array}{c}0.056 \\
(0.120)\end{array}$ & $\begin{array}{l}-0.133 \\
(0.089)\end{array}$ & $\begin{array}{c}0.062 \\
(0.121)\end{array}$ & $\begin{array}{l}-0.022 \\
(0.140)\end{array}$ \\
\hline Abnormal return_1 & $\begin{array}{c}0.592 \\
(0.398)\end{array}$ & $\begin{array}{c}-1.010 * * * \\
(0.291)\end{array}$ & $\begin{array}{c}0.372 \\
(0.418)\end{array}$ & $\begin{array}{c}1.666^{* * *} \\
(0.465)\end{array}$ \\
\hline Abnormal return_2 & $\begin{array}{l}0.844^{*} \\
(0.438)\end{array}$ & $\begin{array}{c}-1.052 * * * \\
(0.320)\end{array}$ & $\begin{array}{c}0.640 \\
(0.459)\end{array}$ & $\begin{array}{c}0.667 \\
(0.531)\end{array}$ \\
\hline Market Momentum & $\begin{array}{c}0.086 \\
(0.106)\end{array}$ & $\begin{array}{l}-0.035 \\
(0.078)\end{array}$ & $\begin{array}{c}0.080 \\
(0.107)\end{array}$ & $\begin{array}{c}0.079 \\
(0.122)\end{array}$ \\
\hline SEO Leverage & $\begin{array}{c}0.148 * * * \\
(0.043)\end{array}$ & $\begin{array}{c}0.068 * * \\
(0.031)\end{array}$ & $\begin{array}{c}0.164 * * * \\
(0.044)\end{array}$ & $\begin{array}{c}0.073 \\
(0.102)\end{array}$ \\
\hline Market_to_Book & $\begin{array}{c}0.099 * * * \\
(0.035)\end{array}$ & $\begin{array}{c}0.040 \\
(0.026)\end{array}$ & $\begin{array}{c}0.103 * * * \\
(0.036)\end{array}$ & $\begin{array}{c}0.092 * * \\
(0.046)\end{array}$ \\
\hline Underwriter Reputation_SEO & $\begin{array}{l}-0.071 \\
(0.109)\end{array}$ & $\begin{array}{c}-0.072 \\
(0.080)\end{array}$ & $\begin{array}{l}-0.100 \\
(0.112)\end{array}$ & $\begin{array}{l}-0.125 \\
(0.128)\end{array}$ \\
\hline Board Independence & $\begin{array}{c}1.536 * * * \\
(0.346)\end{array}$ & $\begin{array}{c}-1.936 * * * \\
(0.257)\end{array}$ & $\begin{array}{c}1.284 * * * \\
(0.375)\end{array}$ & $\begin{array}{l}-1.218 \\
(1.043)\end{array}$ \\
\hline CEO Ownership & $\begin{array}{l}-0.786 \\
(0.611)\end{array}$ & $\begin{array}{l}-0.213 \\
(0.449)\end{array}$ & $\begin{array}{l}-0.829 \\
(0.620)\end{array}$ & $\begin{array}{l}-1.090 \\
(0.942)\end{array}$ \\
\hline Ownership Concentration & $\begin{array}{l}0.011 * * \\
(0.005)\end{array}$ & $\begin{array}{c}-0.007 * * \\
(0.003)\end{array}$ & $\begin{array}{c}0.010 * * \\
(0.005)\end{array}$ & $\begin{array}{c}0.005 \\
(0.005)\end{array}$ \\
\hline Board Size & $\begin{array}{c}0.051 * * \\
(0.024)\end{array}$ & $\begin{array}{l}-0.001 \\
(0.017)\end{array}$ & $\begin{array}{c}0.051 * * \\
(0.024)\end{array}$ & $\begin{array}{l}0.042 * \\
(0.024)\end{array}$ \\
\hline IPO Oversubscription & & $\begin{array}{c}0.367 * * * \\
(0.031)\end{array}$ & & \\
\hline Constant & $\begin{array}{c}-1.101 * * * \\
(0.388)\end{array}$ & $\begin{array}{c}0.247 \\
(0.355)\end{array}$ & $\begin{array}{l}-0.406 \\
(0.501)\end{array}$ & $\begin{array}{c}-1.083 * * \\
(0.447)\end{array}$ \\
\hline Inverse Mill's ratio & & & & $\begin{array}{c}0.818^{* * *} \\
(0.296)\end{array}$ \\
\hline Industry \&Year & Yes & Yes & Yes & Yes \\
\hline Observations & 804 & 804 & 804 & 1708 \\
\hline Adjusted $\mathrm{R}^{2}$ & 0.190 & 0.211 & 0.172 & \\
\hline F-test (joint test) & $16.69 * * *$ & & $17.47 * * *$ & \\
\hline Wald Chi2 & & & & $122.07 * * *$ \\
\hline Hausman test & & & $39.10 * * *$ & \\
\hline
\end{tabular}


Table 6. IPO performance impact on SEO issuance and proceeds: the relevance of state influence

This table reports the regression results for SEO performance, IPO Underpricing and other control variables using Chinese firms' data over the period 1990 to 2015 . The full sample is split based on whether the firm is strongly influenced by the state (State Owned). The dependent variable in panel A is SEO Time, which is 1 if the firm issued its first SEO within 3 years after IPO, 0 otherwise. The dependent variable in panel B is SEO Relative Size, which is ratio of proceeds raised by the first SEO divided by proceeds raised during IPO; it is 0 if the firm does not issue any SEO. All variables are defined in the Appendix. IV/IV-logit approach is applied in this table. IPO Oversubscription is used as an instrumental variable in the MLE and IV methods. The corresponding first-stage coefficients are not reported for brevity. The standard errors reported in the parentheses are adjusted for heteroscedasticity. The results control for the year and industry effects. $(*)(* *)(* * *)$ indicates that the coefficient is significant at the $10 \%(5 \%)(1 \%)$ level, respectively.

\begin{tabular}{|c|c|c|c|c|c|c|}
\hline & \multicolumn{3}{|c|}{ Panel A. SEO Time } & \multicolumn{3}{|c|}{ Panel B. SEO Relative Size } \\
\hline & $(1)$ & $(2)$ & (3) & $(4)$ & $(5)$ & $(6)$ \\
\hline & State Owned & Non-State Owned & Full sample & State Owned & Non-State Owned & Full sample \\
\hline IPO Underpricing & $\begin{array}{l}-0.070 \\
(0.088)\end{array}$ & $\begin{array}{c}0.435^{* * *} * \\
(0.085)\end{array}$ & $\begin{array}{c}0.296^{* * *} * \\
(0.098)\end{array}$ & $\begin{array}{c}1.467 * * * \\
(0.245)\end{array}$ & $\begin{array}{c}1.809^{* * *} \\
(0.172)\end{array}$ & $\begin{array}{c}1.584 * * * \\
(0.176)\end{array}$ \\
\hline State Owned & & & $\begin{array}{c}1.007 * * * \\
(0.130)\end{array}$ & & & $\begin{array}{c}0.789^{* * * *} \\
(0.151)\end{array}$ \\
\hline IPO Underpricing* State Owned & & & $\begin{array}{c}-0.268^{* * * *} \\
(0.099)\end{array}$ & & & $\begin{array}{c}-0.251 * * * \\
(0.075)\end{array}$ \\
\hline Shanghai & $\begin{array}{c}0.034 \\
(0.104)\end{array}$ & $\begin{array}{c}0.329 * * \\
(0.133)\end{array}$ & $\begin{array}{c}0.192 * * \\
(0.084)\end{array}$ & $\begin{array}{c}-0.381 * \\
(0.210)\end{array}$ & $\begin{array}{l}-0.096 \\
(0.216)\end{array}$ & $\begin{array}{c}-0.184 \\
(0.144)\end{array}$ \\
\hline Abnormal return_1 & $\begin{array}{c}-0.149 \\
(0.455)\end{array}$ & $\begin{array}{c}0.556 \\
(0.393)\end{array}$ & $\begin{array}{c}0.289 \\
(0.284)\end{array}$ & $\begin{array}{c}2.216^{* * *} \\
(0.840)\end{array}$ & $\begin{array}{c}1.561 * * \\
(0.626)\end{array}$ & $\begin{array}{c}1.413 * * * \\
(0.499)\end{array}$ \\
\hline Abnormal return_2 & $\begin{array}{c}1.289 * * * \\
(0.475)\end{array}$ & $\begin{array}{c}0.902 * * \\
(0.439)\end{array}$ & $\begin{array}{c}0.999 * * * \\
(0.313)\end{array}$ & $\begin{array}{c}2.595 * * * \\
(0.940)\end{array}$ & $\begin{array}{c}2.601 * * * \\
(0.687)\end{array}$ & $\begin{array}{c}2.676^{* * *} \\
(0.544)\end{array}$ \\
\hline Market Momentum & $\begin{array}{c}-0.278^{* * *} \\
(0.105)\end{array}$ & $\begin{array}{l}-0.106 \\
(0.103)\end{array}$ & $\begin{array}{c}-0.214 * * * \\
(0.072)\end{array}$ & $\begin{array}{c}-0.282 \\
(0.208)\end{array}$ & $\begin{array}{c}-0.402 * * \\
(0.163)\end{array}$ & $\begin{array}{c}-0.364 * * * \\
(0.126)\end{array}$ \\
\hline Constant & $\begin{array}{l}-0.385 \\
(0.260)\end{array}$ & $\begin{array}{c}-1.594 * * * \\
(0.243)\end{array}$ & $\begin{array}{c}-1.539^{* * *} \\
(0.183)\end{array}$ & $\begin{array}{c}-3.165^{* *} \\
(1.409)\end{array}$ & $\begin{array}{c}-2.393^{* * *} \\
(0.401)\end{array}$ & $\begin{array}{c}-2.182^{* * *} \\
(0.316)\end{array}$ \\
\hline Industry \&Year & Yes & Yes & Yes & Yes & Yes & Yes \\
\hline Observations & 627 & 1,081 & 1,708 & 627 & 1,081 & 1,708 \\
\hline Wald Chi2 & $21.55^{* * *}$ & $58.91 * * *$ & $193.67 * * *$ & $153.52 * * *$ & $148.43 * * *$ & $300.59 * * *$ \\
\hline
\end{tabular}


Table 7. IPO performance impact on SEO issuance and proceeds: the relevance of political connectedness

This table reports the regression results for SEO performance, IPO Underpricing and other control variables using Chinese firms' data over the period 1990 to 2015 . The full sample is split based on whether the firm is politically connected. We define firms as politically linked if their CEO or chairperson currently holds or previously held a position as an officer in the Chinese state (Political Connection). The dependent variable in panel A is SEO Time, which is 1 if the firm issued its first SEO within 3 years after IPO, 0 otherwise. The dependent variable in panel $\mathrm{B}$ is SEO Relative Size, which is ratio of proceeds raised by the first SEO divided by proceeds raised during IPO; it is 0 if the firm does not issue any SEO. All variables are defined in the Appendix. Three estimation procedures are used: Logit (panel A), Maximum likelihood (panel B) and generated IV approach (panel C). IPO Oversubscription is used as an instrumental variable in the MLE and IV methods. The corresponding first-stage coefficients are not reported for brevity. The standard errors reported in the parentheses are adjusted for heteroscedasticity. The results control for the year and industry effects. $(*)(* *)(* * *)$ indicates that the coefficient is significant at the $10 \%(5 \%)(1 \%)$ level, respectively.

\begin{tabular}{|c|c|c|c|c|c|c|}
\hline & \multicolumn{3}{|c|}{ Panel A. SEO Time } & \multicolumn{3}{|c|}{ Panel B. SEO Relative Size } \\
\hline & (1) & (2) & (3) & (4) & $(5)$ & (6) \\
\hline & $\begin{array}{l}\text { With Political } \\
\text { Connection }\end{array}$ & $\begin{array}{l}\text { Without Political } \\
\text { Connection }\end{array}$ & Full sample & $\begin{array}{l}\text { With Political } \\
\text { Connection }\end{array}$ & $\begin{array}{l}\text { Without Political } \\
\text { Connection }\end{array}$ & Full sample \\
\hline IPO Underpricing & $\begin{array}{c}0.160^{* *} \\
(0.080)\end{array}$ & $\begin{array}{c}0.472 * * * \\
(0.109)\end{array}$ & $\begin{array}{c}0.405^{* *} \\
(0.165)\end{array}$ & $\begin{array}{c}1.234 * * * \\
(0.221)\end{array}$ & $\begin{array}{c}1.733^{* * * *} \\
(0.193)\end{array}$ & $\begin{array}{c}2.217 * * * \\
(0.271)\end{array}$ \\
\hline Political Connection & & & $\begin{array}{l}0.598^{* *} \\
(0.285)\end{array}$ & & & $\begin{array}{c}0.768 * * * \\
(0.258)\end{array}$ \\
\hline IPO Underpricing* Political Connection & & & $\begin{array}{c}-0.589 * * \\
(0.292)\end{array}$ & & & $\begin{array}{c}-1.424 * * * \\
(0.277)\end{array}$ \\
\hline Shanghai & $\begin{array}{c}0.241 * * \\
(0.114)\end{array}$ & $\begin{array}{c}0.684 * * * \\
(0.110)\end{array}$ & $\begin{array}{c}0.425 * * * \\
(0.083)\end{array}$ & $\begin{array}{l}-0.027 \\
(0.233)\end{array}$ & $\begin{array}{l}0.246 \\
(0.155)\end{array}$ & $\begin{array}{c}0.139 \\
(0.136)\end{array}$ \\
\hline Abnormal return_1 & $\begin{array}{c}0.398 \\
(0.488)\end{array}$ & $\begin{array}{c}0.256 \\
(0.366)\end{array}$ & $\begin{array}{c}0.054 \\
(0.285)\end{array}$ & $\begin{array}{c}1.319 \\
(1.003)\end{array}$ & $\begin{array}{l}1.060 * * \\
(0.497)\end{array}$ & $\begin{array}{l}1.033 * * \\
(0.479)\end{array}$ \\
\hline Abnormal return_2 & $\begin{array}{c}0.532 \\
(0.520)\end{array}$ & $\begin{array}{c}1.576 * * * \\
(0.393)\end{array}$ & $\begin{array}{c}0.971^{* * *} \\
(0.311)\end{array}$ & $\begin{array}{c}2.941^{* * *} \\
(1.085)\end{array}$ & $\begin{array}{c}2.294 * * * \\
(0.535)\end{array}$ & $\begin{array}{c}2.522 * * * \\
(0.520)\end{array}$ \\
\hline Market Momentum & $\begin{array}{c}-0.245 * * \\
(0.111)\end{array}$ & $\begin{array}{c}-0.219 * * \\
(0.094)\end{array}$ & $\begin{array}{c}-0.267 * * * \\
(0.071)\end{array}$ & $\begin{array}{l}-0.158 \\
(0.231)\end{array}$ & $\begin{array}{c}-0.501 * * * \\
(0.131)\end{array}$ & $\begin{array}{c}-0.389 * * * \\
(0.122)\end{array}$ \\
\hline Constant & $\begin{array}{c}-1.113^{* * * *} \\
(0.271)\end{array}$ & $\begin{array}{c}-1.380^{* * * *} \\
(0.231)\end{array}$ & $\begin{array}{c}-1.322 * * * \\
(0.210)\end{array}$ & $\begin{array}{c}-2.136 * * * \\
(0.575)\end{array}$ & $\begin{array}{c}-1.724 * * * \\
(0.329)\end{array}$ & $\begin{array}{c}-2.202 * * * \\
(0.336)\end{array}$ \\
\hline Industry \&Year & Yes & Yes & Yes & Yes & Yes & Yes \\
\hline Observations & 613 & 1,095 & 1,708 & 613 & 1,095 & 1,708 \\
\hline Wald Chi2 & $19.99 * * *$ & $100.04 * * *$ & $99.60 * * *$ & $38.39 * *$ & $143.14 * * *$ & $241.01 * * *$ \\
\hline
\end{tabular}


Table 8. IPO performance impact on SEO issuance and proceeds: the relevance of location as economic development area.

This table reports the regression results for SEO performance, IPO Underpricing and other control variables using Chinese firms' data over the period 1990 to 2015 . The full sample is split based on whether the firm's headquarter is located in one of the economic development areas (EDA) (Location). The dependent variable in panel A is SEO Time, which is 1 if the firm issued its first SEO within 3 years after IPO, 0 otherwise. The dependent variable in panel B is SEO Relative Size, which is ratio of proceeds raised by the first SEO divided by proceeds raised during IPO; it is 0 if the firm does not issue any SEO. All variables are defined in the Appendix. Three estimation procedures are used: Logit (panel A), Maximum likelihood (panel B) and generated IV approach (panel C). IPO Oversubscription is used as an instrumental variable in the MLE and IV methods. The corresponding first-stage coefficients are not reported for brevity. The standard errors reported in the parentheses are adjusted for heteroscedasticity. The results control for the year and industry effects. $(*)$ $(* *)(* * *)$ indicates that the coefficient is significant at the $10 \%(5 \%)(1 \%)$ level, respectively.

\begin{tabular}{|c|c|c|c|c|c|c|}
\hline & \multicolumn{3}{|c|}{ Panel A. SEO Time } & \multicolumn{3}{|c|}{ Panel B. SEO Relative Size } \\
\hline & $(1)$ & $(2)$ & (3) & $(4)$ & $(5)$ & $(6)$ \\
\hline & EDA & Non-EDA & Full sample & EDA & Non-EDA & Full sample \\
\hline IPO Underpricing & $\begin{array}{c}0.070 \\
(0.066)\end{array}$ & $\begin{array}{c}0.513 * * * \\
(0.124)\end{array}$ & $\begin{array}{c}0.169 * * \\
(0.085)\end{array}$ & $\begin{array}{c}1.277 * * * \\
(0.207)\end{array}$ & $\begin{array}{c}1.518^{* * * *} \\
(0.179)\end{array}$ & $\begin{array}{c}1.677 * * * \\
(0.203)\end{array}$ \\
\hline Location & & & $\begin{array}{l}-0.174 \\
(0.155)\end{array}$ & & & $\begin{array}{c}0.288 \\
(0.259)\end{array}$ \\
\hline IPO Underpricing* Location & & & $\begin{array}{c}-0.286^{* *} \\
(0.142)\end{array}$ & & & $\begin{array}{c}-0.650 * * * \\
(0.213)\end{array}$ \\
\hline Shanghai & $\begin{array}{c}0.267 * * * \\
(0.097)\end{array}$ & $\begin{array}{c}0.728^{* * *} \\
(0.152)\end{array}$ & $\begin{array}{c}0.444 * * * \\
(0.079)\end{array}$ & $\begin{array}{c}0.270 \\
(0.221)\end{array}$ & $\begin{array}{l}-0.127 \\
(0.181)\end{array}$ & $\begin{array}{c}0.027 \\
(0.141)\end{array}$ \\
\hline Abnormal return_1 & $\begin{array}{l}-0.143 \\
(0.336)\end{array}$ & $\begin{array}{c}1.262 * * \\
(0.548)\end{array}$ & $\begin{array}{c}0.220 \\
(0.275)\end{array}$ & $\begin{array}{c}2.253 * * * \\
(0.838)\end{array}$ & $\begin{array}{c}0.799 \\
(0.613)\end{array}$ & $\begin{array}{l}1.225^{* *} \\
(0.495)\end{array}$ \\
\hline Abnormal return_2 & $\begin{array}{c}0.936 * * * \\
(0.357)\end{array}$ & $\begin{array}{c}1.817 * * * \\
(0.611)\end{array}$ & $\begin{array}{c}1.067 * * * \\
(0.300)\end{array}$ & $\begin{array}{c}2.406^{* * * *} \\
(0.901)\end{array}$ & $\begin{array}{c}2.822 * * * \\
(0.658)\end{array}$ & $\begin{array}{c}2.654^{* * * *} \\
(0.535)\end{array}$ \\
\hline Market Momentum & $\begin{array}{c}-0.153^{*} \\
(0.084)\end{array}$ & $\begin{array}{c}-0.450 * * * \\
(0.132)\end{array}$ & $\begin{array}{c}-0.252 * * * \\
(0.069)\end{array}$ & $\begin{array}{c}-0.470 * * \\
(0.204)\end{array}$ & $\begin{array}{c}-0.374 * * \\
(0.156)\end{array}$ & $\begin{array}{c}-0.419^{* * *} \\
(0.124)\end{array}$ \\
\hline Constant & $\begin{array}{c}-1.098^{* * *} \\
(0.265)\end{array}$ & $\begin{array}{c}-1.315^{* * *} \\
(0.240)\end{array}$ & $\begin{array}{c}-1.073 * * * \\
(0.202)\end{array}$ & $\begin{array}{c}-1.852^{* * * *} \\
(0.399)\end{array}$ & $\begin{array}{c}-1.739 * * * \\
(0.473)\end{array}$ & $\begin{array}{c}-1.944 * * * \\
(0.368)\end{array}$ \\
\hline Industry \&Year & Yes & Yes & Yes & Yes & Yes & Yes \\
\hline Observations & 621 & 1,087 & 1,708 & 621 & 1,087 & 1,708 \\
\hline Wald Chi2 & $27.10 * * *$ & $90.35 * * *$ & $125.41 * * *$ & $67.99 * * *$ & $105.17 * * *$ & $239.40 * * *$ \\
\hline
\end{tabular}


Table 9. IPO underpricing impact on SEO issuance and proceeds: the presence of state ownership.

This table reports the regression results for SEO performance, IPO Underpricing and other control variables using Chinese firms' data over the period 1990 to 2015 . The full sample is split based on whether the firm has any state ownership (State Present). The dependent variable in panel A is SEO Time, which is 1 if the firm issued its first SEO within 3 years after IPO, 0 otherwise. The dependent variable in panel B is SEO Relative Size, which is ratio of proceeds raised by the first SEO divided by proceeds raised during IPO; it is 0 if the firm does not issue any SEO. All variables are defined in the Appendix. Three estimation procedures are used: Logit (panel A), Maximum likelihood (panel B) and generated IV approach (panel C). IPO Oversubscription is used as an instrumental variable in the MLE and IV methods. The corresponding first-stage coefficients are not reported for brevity. The standard errors reported in the parentheses are adjusted for heteroscedasticity. The results control for the year and industry effects. $(*)(* *)(* * *)$ indicates that the coefficient is significant at the $10 \%(5 \%)(1 \%)$ level, respectively.

\begin{tabular}{|c|c|c|c|c|c|c|}
\hline & \multicolumn{3}{|c|}{ Panel A. SEO Time } & \multicolumn{3}{|c|}{ Panel B. SEO Relative Size } \\
\hline & (1) & $(2)$ & (3) & $(4)$ & $(5)$ & (6) \\
\hline & $\begin{array}{l}\text { With State } \\
\text { Ownership }\end{array}$ & $\begin{array}{l}\text { Without State } \\
\text { Ownership }\end{array}$ & Full sample & With State Ownership & $\begin{array}{l}\text { Without State } \\
\text { Ownership }\end{array}$ & Full sample \\
\hline IPO Underpricing & $\begin{array}{l}-0.035 \\
(0.085)\end{array}$ & $\begin{array}{c}0.536^{* * *} \\
(0.102)\end{array}$ & $\begin{array}{l}0.298^{*} \\
(0.160)\end{array}$ & $\begin{array}{c}0.977 * * * \\
(0.199)\end{array}$ & $\begin{array}{c}2.094 * * * \\
(0.217)\end{array}$ & $\begin{array}{c}2.063 * * * \\
(0.290)\end{array}$ \\
\hline State Present & & & $\begin{array}{c}1.008 * * * \\
(0.266)\end{array}$ & & & $\begin{array}{c}1.727 * * * \\
(0.274)\end{array}$ \\
\hline IPO Underpricing*State Present & & & $\begin{array}{c}-0.337 \\
(0.266)\end{array}$ & & & $\begin{array}{c}-1.182^{* * *} \\
(0.296)\end{array}$ \\
\hline Shanghai & $\begin{array}{c}0.012 \\
(0.091)\end{array}$ & $\begin{array}{c}0.747 * * * \\
(0.179)\end{array}$ & $\begin{array}{c}0.197 * * \\
(0.093)\end{array}$ & $\begin{array}{c}-0.382 * * \\
(0.164)\end{array}$ & $\begin{array}{c}0.022 \\
(0.281)\end{array}$ & $\begin{array}{l}-0.251^{*} \\
(0.147)\end{array}$ \\
\hline Abnormal return_1 & $\begin{array}{l}-0.142 \\
(0.375)\end{array}$ & $\begin{array}{c}1.341 * * * \\
(0.514)\end{array}$ & $\begin{array}{c}0.363 \\
(0.287)\end{array}$ & $\begin{array}{c}0.611 \\
(0.688)\end{array}$ & $\begin{array}{c}2.554 * * * \\
(0.724)\end{array}$ & $\begin{array}{c}1.600 * * * \\
(0.508)\end{array}$ \\
\hline Abnormal return_2 & $\begin{array}{l}0.801^{*} \\
(0.423)\end{array}$ & $\begin{array}{l}0.962^{*} \\
(0.550)\end{array}$ & $\begin{array}{c}0.922 * * * \\
(0.325)\end{array}$ & $\begin{array}{c}2.864 * * * \\
(0.775)\end{array}$ & $\begin{array}{l}1.672 * * \\
(0.763)\end{array}$ & $\begin{array}{c}2.291 * * * \\
(0.540)\end{array}$ \\
\hline Market Momentum & $\begin{array}{c}-0.272 * * * \\
(0.089)\end{array}$ & $\begin{array}{l}-0.094 \\
(0.133)\end{array}$ & $\begin{array}{c}-0.217 * * * \\
(0.072)\end{array}$ & $\begin{array}{c}-0.332 * * \\
(0.166)\end{array}$ & $\begin{array}{c}-0.392 * * \\
(0.187)\end{array}$ & $\begin{array}{c}-0.367 * * * \\
(0.126)\end{array}$ \\
\hline Constant & $\begin{array}{c}-0.598 * * * \\
(0.210)\end{array}$ & $\begin{array}{c}-2.026^{* * * *} \\
(0.333)\end{array}$ & $\begin{array}{c}-1.659 * * * \\
(0.231)\end{array}$ & $\begin{array}{c}-0.889 * * \\
(0.411)\end{array}$ & $\begin{array}{c}-3.045^{* * *} \\
(0.486)\end{array}$ & $\begin{array}{c}-2.740 * * * \\
(0.372)\end{array}$ \\
\hline Industry \&Year & Yes & Yes & Yes & Yes & Yes & Yes \\
\hline Observations & 860 & 848 & 1708 & 860 & 848 & 1708 \\
\hline Wald Chi2 & $22.30 * * *$ & $74.65 * * *$ & $185.13 * * *$ & $42.44 * * *$ & $123.03 * * *$ & $346.73 * * *$ \\
\hline
\end{tabular}


Table 10. IPO underpricing impact on SEO issuance and proceeds: the state as the major shareholder.

This table reports the regression results for SEO performance, IPO Underpricing and other control variables using Chinese firms' data over the period 1990 to 2015 . The full sample is split based on whether the firm has state ownership more than 50 percent of its shareholdings (State Major). Low (high) state ownership subsample is for firms with less (more) than $50 \%$ of shares held by the state. The dependent variable in panel A is SEO Time, which is 1 if the firm issued its first SEO within 3 years after IPO, 0 otherwise. The dependent variable in panel B is SEO Relative Size, which is ratio of proceeds raised by the first SEO divided by proceeds raised during IPO; it is 0 if the firm does not issue any SEO. All variables are defined in the Appendix. Three estimation procedures are used: Logit (panel A), Maximum likelihood (panel B) and generated IV approach (panel C). IPO Oversubscription is used as an instrumental variable in the MLE and IV methods. The corresponding first-stage coefficients are not reported for brevity. The standard errors reported in the parentheses are adjusted for heteroscedasticity. The results control for the year and industry effects. $(*)(* *)(* * *)$ indicates that the coefficient is significant at the $10 \%(5 \%)(1 \%)$ level, respectively.

\begin{tabular}{|c|c|c|c|c|c|c|}
\hline & \multicolumn{3}{|c|}{ Panel A. SEO Time } & \multicolumn{3}{|c|}{ Panel B. SEO Relative Size } \\
\hline & $(1)$ & $(2)$ & (3) & $(4)$ & $(5)$ & $(6)$ \\
\hline & $\begin{array}{l}\text { High State } \\
\text { Ownership }\end{array}$ & $\begin{array}{l}\text { Low State } \\
\text { Ownership }\end{array}$ & Full sample & $\begin{array}{l}\text { High State } \\
\text { Ownership }\end{array}$ & $\begin{array}{l}\text { Low State } \\
\text { Ownership }\end{array}$ & Full sample \\
\hline IPO Underpricing & $\begin{array}{l}-0.143 \\
(0.104)\end{array}$ & $\begin{array}{c}0.491 * * * \\
(0.087)\end{array}$ & $\begin{array}{c}0.290 * * * \\
(0.099)\end{array}$ & $\begin{array}{c}0.961 * * * \\
(0.269)\end{array}$ & $\begin{array}{c}1.775 * * * \\
(0.170)\end{array}$ & $\begin{array}{c}1.762 * * * \\
(0.202)\end{array}$ \\
\hline State Major & & & $\begin{array}{c}1.077 * * * \\
(0.218)\end{array}$ & & & $\begin{array}{c}1.556^{* * * *} \\
(0.268)\end{array}$ \\
\hline IPO Underpricing*State Major & & & $\begin{array}{c}-0.378^{* *} \\
(0.180)\end{array}$ & & & $\begin{array}{c}-0.901 * * * \\
(0.219)\end{array}$ \\
\hline Shanghai & $\begin{array}{l}-0.170 \\
(0.110)\end{array}$ & $\begin{array}{c}0.449 * * * \\
(0.146)\end{array}$ & $\begin{array}{l}0.158^{*} \\
(0.094)\end{array}$ & $\begin{array}{c}-0.445 * * \\
(0.194)\end{array}$ & $\begin{array}{c}-0.094 \\
(0.225)\end{array}$ & $\begin{array}{c}-0.286^{*} \\
(0.153)\end{array}$ \\
\hline Abnormal return_1 & $\begin{array}{l}-0.014 \\
(0.469)\end{array}$ & $\begin{array}{c}0.963 * * \\
(0.423)\end{array}$ & $\begin{array}{c}0.345 \\
(0.290)\end{array}$ & $\begin{array}{c}1.329 \\
(0.822)\end{array}$ & $\begin{array}{c}1.715 * * * \\
(0.633)\end{array}$ & $\begin{array}{c}1.579 * * * \\
(0.508)\end{array}$ \\
\hline Abnormal return_2 & $\begin{array}{c}0.578 \\
(0.533)\end{array}$ & $\begin{array}{l}1.063 * * \\
(0.459)\end{array}$ & $\begin{array}{c}0.936^{* * * *} \\
(0.316)\end{array}$ & $\begin{array}{c}2.298^{* *} \\
(0.939)\end{array}$ & $\begin{array}{c}2.538 * * * \\
(0.683)\end{array}$ & $\begin{array}{c}2.428 * * * \\
(0.537)\end{array}$ \\
\hline Market Momentum & $\begin{array}{c}-0.332 * * * \\
(0.112)\end{array}$ & $\begin{array}{l}-0.006 \\
(0.109)\end{array}$ & $\begin{array}{c}-0.205 * * * \\
(0.072)\end{array}$ & $\begin{array}{c}-0.311 \\
(0.194)\end{array}$ & $\begin{array}{c}-0.366^{* * *} \\
(0.164)\end{array}$ & $\begin{array}{c}-0.335 * * * \\
(0.127)\end{array}$ \\
\hline Constant & $\begin{array}{c}-0.343 \\
(0.251)\end{array}$ & $\begin{array}{c}-1.893 * * * \\
(0.270)\end{array}$ & $\begin{array}{c}-1.572 * * * \\
(0.202)\end{array}$ & $\begin{array}{l}-0.697 \\
(0.492)\end{array}$ & $\begin{array}{c}-2.674 * * * \\
(0.416)\end{array}$ & $\begin{array}{c}-2.474 * * * \\
(0.346)\end{array}$ \\
\hline Industry \&Year & Yes & Yes & Yes & Yes & Yes & Yes \\
\hline Observations & 609 & 1099 & 1708 & 609 & 1099 & 1708 \\
\hline Wald Chi2 & $24.44 * * *$ & $83.29 * * *$ & $174.62 * * *$ & $26.03 * * *$ & $155.05 * * *$ & $286.59 * * *$ \\
\hline
\end{tabular}




\section{Internet Appendix for}

\section{The impact of governmental intervention on the association between initial public offering and future stock issuance}

This appendix provides the following empirical tests:

Table IA.1 presents regulation changes and stock issuance.

Table IA.2 presents regulation changes and stock issuance with propensity score matching.

Table IA.3 presents IPO underpricing impact on the time gap between SEO and IPO.

Table IA.4 Propensity score matched regression between SOE and non-SOE.

Table IA.5 presents Effect of IPO underpricing on first SEO issuance.

Table IA.6 presents Effect of IPO underpricing on SEO proceeds.

Table IA.7 presents The Sources of SEO Relative Size: Heckman Procedure.

Table IA.8 presents IPO performance impact on SEO issuance decisions: the relevance of the State ownership.

Table IA.9 IPOs performance impact on SEO proceeds.

Table IA.10 Distribution of state ownership for IPOs. 
Table IA.1: Regulation changes and stock issuance

This table reports the connection between IPO underpricing and SEO performance along with regulation changes, using IV approach to control potential endogeneity issues. Panel A presents the results between private placement and right issue/public offering; Panel B shows the regression results by different IPO allocation mechanism (Book building and others); The standard errors reported in the parentheses are adjusted for heteroscedasticity. The results control for the year and industry effects. $*(* *)(* * *)$ indicates that the coefficient is significant at the $10 \%(5 \%)(1 \%)$ level, respectively.

Panel A: Sub-groups by different SEO issue methods

IPO Underpricing

Shanghai

Abnormal return_1

Abnormal return_2

Market Momentum

Constant

$\mathrm{N}$

Wald chi2

Wald chi 2

IPO Underpricing

Shanghai

Abnormal return_1

Abnormal return_2

Market Momentum

Constant

$\mathrm{N}$

Wald chi2
(1) (2)

Dependent Variable: SEO within 3 years Booking Building $0.735 * * *$

$(0.160)$

.

$1.295 * *$

(0.543)

$1.117^{* *}$

(0.556)

0.065

$(0.140)$

$-2.203 * * *$

(0.340)

835

$25.25 * * *$
Others

$-0.180$

$(0.126)$

$-0.120$

$(0.094)$

$-0.002$

$(0.388)$

0.217

(0.458)

$-0.266^{* * *}$

(0.094)

0.217

(0.291)

791

$14.41^{* *}$
(1)

Dependent Variable: SEO within 3 years

(3)

Dependent Variable: SEO relative size Private placement Right issue/public offering

$$
\begin{gathered}
1.557 * * * \\
(0.221) \\
-2.125^{* * *} \\
(0.434) \\
2.208^{* *} \\
(0.866) \\
2.693 * * * \\
(0.903) \\
-0.598 * * * \\
(0.219) \\
-1.514 * * * \\
(0.519) \\
624
\end{gathered}
$$$$
\text { (0.168) }
$$$$
(0.099)
$$$$
0.287 * * *
$$$$
(0.091)
$$$$
0.572 * * *
$$$$
(0.160)
$$$$
0.574
$$$$
(0.595)
$$$$
2.421 * * *
$$

$-0.359 * *$

$(0.155)$

(0.083)

(0.396)

$(0.210)$

1084

$85.59 * * *$

$(0.147)$

$-1.979 * * *$

$(0.369)$

1084

$129.03^{* * *}$

Panel B: Sub-groups by different IPO allocation mechanisms

(3)

(4)

Dependent Variable: SEO relative size Booking Building Others

$\begin{array}{cc}2.087 * * * & 0.770 * * * \\ (0.233) & (0.213) \\ -3.055^{* * *} & -0.324 * * \\ (0.762) & (0.163) \\ 2.691 * * * & 0.502 \\ (0.751) & (0.659) \\ 1.575 * * & 2.253 * * * \\ (0.765) & (0.774) \\ -0.440 * * & -0.265 \\ (0.187) & (0.162) \\ -2.413 * * * & -0.283 \\ (0.459) & (0.497) \\ 917 & 791 \\ 104.40 * * * & 26.02 * * *\end{array}$


Table IA.2: Regulation changes and stock issuance with PSM

This table reports the connection between IPO underpricing and SEO performance of a subsample of firm based on Propensity score matching along with regulation changes, using IV approach to control potential endogeneity issues. Panel A presents the results between private placement and right issue/public offering; Panel B shows the regression results by different IPO allocation mechanism (Book building and others); The standard errors reported in the parentheses are adjusted for heteroscedasticity. The results control for the year and industry effects. $*(* *)(* * *)$ indicates that the coefficient is significant at the $10 \%(5 \%)(1 \%)$ level, respectively.

\begin{tabular}{|c|c|c|c|c|}
\hline \multicolumn{5}{|c|}{ Panel A: Sub-groups by different SEO issue methods } \\
\hline & $(1)$ & $(2)$ & (3) & (4) \\
\hline & \multicolumn{2}{|c|}{ Dependent Variable: SEO within 3 years } & \multicolumn{2}{|c|}{ Dependent Variable: SEO relative size } \\
\hline & Private placement & Right issue/public offering & Private placement & Right issue/public offering \\
\hline \multirow[t]{2}{*}{ IPO Underpricing } & $0.625 * * *$ & $0.440^{* *}$ & $1.557 * * *$ & $1.133^{* * *}$ \\
\hline & $(0.156)$ & $(0.184)$ & $(0.221)$ & $(0.279)$ \\
\hline \multirow[t]{2}{*}{ Shanghai } & $-1.019 * *$ & $0.435 * *$ & $-2.125 * * *$ & $1.062 * * *$ \\
\hline & $(0.431)$ & $(0.170)$ & $(0.434)$ & $(0.249)$ \\
\hline \multirow[t]{2}{*}{ Abnormal return_1 } & $1.263 * *$ & 0.174 & $2.208 * *$ & 0.345 \\
\hline & $(0.597)$ & $(0.497)$ & $(0.866)$ & $(0.742)$ \\
\hline \multirow[t]{2}{*}{ Abnormal return_2 } & $1.506^{* *}$ & $0.999 * *$ & $2.693 * * *$ & $1.884 * * *$ \\
\hline & $(0.622)$ & $(0.489)$ & $(0.903)$ & $(0.727)$ \\
\hline \multirow[t]{2}{*}{ Market Momentum } & 0.064 & $-0.299 * *$ & $-0.598 * * *$ & $-0.431 * *$ \\
\hline & $(0.155)$ & $(0.117)$ & $(0.219)$ & $(0.176)$ \\
\hline \multirow[t]{2}{*}{ Constant } & $-2.348 * * *$ & $-1.092 * * *$ & $-1.514 * * *$ & $-1.157 * *$ \\
\hline & $(0.396)$ & $(0.347)$ & $(0.519)$ & $(0.520)$ \\
\hline $\mathrm{N}$ & 624 & 624 & 624 & 624 \\
\hline \multirow[t]{5}{*}{ Wald chi2 } & $28.01 * * *$ & $28.58 * * *$ & $85.59 * * *$ & $63.34 * * *$ \\
\hline & \multicolumn{4}{|c|}{ Panel B: Sub-groups by different IPO allocation mechanisms } \\
\hline & (1) & $(2)$ & $(3)$ & $(4)$ \\
\hline & \multicolumn{2}{|c|}{ Dependent Variable: SEO within 3 years } & \multicolumn{2}{|c|}{ Dependent Variable: SEO relative size } \\
\hline & Booking Building & Others & Booking Building & Others \\
\hline \multirow[t]{2}{*}{ IPO Underpricing } & $1.537 * * *$ & -0.180 & $3.982 * * *$ & $0.770 * * *$ \\
\hline & $(0.447)$ & $(0.126)$ & $(0.660)$ & $(0.213)$ \\
\hline \multirow[t]{2}{*}{ Shanghai } & . & -0.120 & . & $-0.324 * *$ \\
\hline & . & $(0.094)$ & . & $(0.163)$ \\
\hline \multirow[t]{2}{*}{ Abnormal return_1 } & 1.023 & -0.002 & $3.188 * * *$ & 0.502 \\
\hline & $(0.678)$ & $(0.388)$ & $(0.979)$ & $(0.659)$ \\
\hline \multirow[t]{2}{*}{ Abnormal return_2 } & $1.892 * *$ & 0.217 & $3.416^{* * *}$ & $2.253 * * *$ \\
\hline & $(0.761)$ & $(0.458)$ & $(1.067)$ & $(0.774)$ \\
\hline \multirow[t]{2}{*}{ Market Momentum } & -0.209 & $-0.266^{* * *}$ & $-0.749 * * *$ & -0.265 \\
\hline & $(0.163)$ & $(0.094)$ & $(0.236)$ & $(0.162)$ \\
\hline \multirow[t]{2}{*}{ Constant } & $-2.291 * * *$ & 0.217 & $-3.121 * * *$ & -0.283 \\
\hline & $(0.411)$ & $(0.291)$ & $(0.603)$ & $(0.497)$ \\
\hline $\mathrm{N}$ & 705 & 791 & 705 & 791 \\
\hline Wald chi2 & $14.92 * *$ & $14.41 * *$ & $43.69 * * *$ & $26.02 * * *$ \\
\hline
\end{tabular}


Table IA.3: IPO underpricing impact on the time gap between SEO and IPO

This table reports the regression results for SEO Time measured by number of months, IPO Underpricing and other control variables using Chinese firms' data over the period 1990 to 2015. The full sample is split based on whether the firm is owned by the state. SEO Time is the dependent variable and takes the value of 1 if the firm issued its first SEO within 3 years after IPO. All variables are defined in the Appendix A1. IV approach is used in this table. IPO oversubscription is used as instrumental variables. The corresponding first-stage coefficients are not reported here for space considerations. The standard errors reported in the parentheses are adjusted for heteroscedasticity. The results control for the year and industry effects. $(*)(* *)(* * *)$ indicates that the coefficient is significant at the $10 \%(5 \%)(1 \%)$ level, respectively.

(1)

\begin{tabular}{|c|c|c|c|}
\hline & Full sample & State Owned & non-State Owned \\
\hline IPO Underpricing & $\begin{array}{c}-0.233 * * * \\
(0.045)\end{array}$ & $\begin{array}{l}-0.141 \\
(0.147)\end{array}$ & $\begin{array}{c}-0.320^{* * *} \\
(0.082)\end{array}$ \\
\hline Shanghai & $\begin{array}{c}0.028 \\
(0.047)\end{array}$ & $\begin{array}{c}0.091 \\
(0.067)\end{array}$ & $\begin{array}{l}-0.079 \\
(0.068)\end{array}$ \\
\hline Abnormal return_1 & $-0.484^{* * *}$ & $-0.484 * * *$ & $-0.516^{*}$ \\
\hline Abnormal return_2 & $\begin{array}{c}(0.162) \\
-0.358^{* *} \\
(0.177)\end{array}$ & $\begin{array}{c}(0.180) \\
0.005 \\
(0.201)\end{array}$ & $\begin{array}{l}(0.275) \\
-0.562 * \\
(0.297)\end{array}$ \\
\hline Market Momentum & $\begin{array}{l}-0.060 \\
(0.041)\end{array}$ & $\begin{array}{c}-0.103^{* * *} \\
(0.050)\end{array}$ & $\begin{array}{l}-0.003 \\
(0.069)\end{array}$ \\
\hline SEO Leverage & $\begin{array}{c}0.094 * * * \\
(0.017)\end{array}$ & $\begin{array}{l}0.060^{*} \\
(0.034)\end{array}$ & $\begin{array}{c}0.083 * * * \\
(0.022)\end{array}$ \\
\hline Market_to_Book & $\begin{array}{c}0.057^{* * * *} \\
(0.014)\end{array}$ & $\begin{array}{c}0.051 * * * \\
(0.018)\end{array}$ & $\begin{array}{c}0.070^{* * * *} \\
(0.021)\end{array}$ \\
\hline Underwriter Reputation_SEO & 0.066 & 0.071 & 0.033 \\
\hline Board Independence & $\begin{array}{c}(0.043) \\
2.063^{* * *} \\
(0.145)\end{array}$ & $\begin{array}{c}(0.050) \\
1.709^{* * * *} \\
(0.190)\end{array}$ & $\begin{array}{c}(0.072) \\
3.026^{* * *} \\
(0.244)\end{array}$ \\
\hline CEO Ownership & $\begin{array}{c}-1.201 * * * \\
(0.239)\end{array}$ & $\begin{array}{c}-0.632 * * * \\
(0.203)\end{array}$ & $\begin{array}{c}-11.546^{* * *} \\
(3.485)\end{array}$ \\
\hline Ownership Concentration & $\begin{array}{c}0.001 \\
(0.002)\end{array}$ & $\begin{array}{l}-0.000 \\
(0.002)\end{array}$ & $\begin{array}{c}0.003 \\
(0.003)\end{array}$ \\
\hline Board Size & $\begin{array}{l}-0.001 \\
(0.009)\end{array}$ & $\begin{array}{l}-0.012 \\
(0.012)\end{array}$ & $\begin{array}{c}0.000 \\
(0.014)\end{array}$ \\
\hline Constant & $\begin{array}{c}3.171^{* * *} \\
(0.193)\end{array}$ & $\begin{array}{c}3.375 * * * \\
(0.224)\end{array}$ & $\begin{array}{c}3.097 * * * \\
(0.330)\end{array}$ \\
\hline Industry \&Year & Yes & Yes & Yes \\
\hline Observations & 804 & 392 & 412 \\
\hline Adjusted $\mathrm{R}^{2}$ & 0.262 & 0.235 & 0.314 \\
\hline $\mathrm{F}$ test & $37.25 * * *$ & $16.93 * * *$ & $20.77 * * *$ \\
\hline
\end{tabular}


Table IA.4: Propensity score matched regression between SOE and non-SOE

This table reports the results of regression of a subsample of (State Owned) treated and control (non-State Owned) firm based on Propensity score matching. Model (1) presents the parameter estimated from the probit model used to estimate the propensity score for firms in the treated and control groups. The dependent variable is one if the firm is SOE and zero if it is non-SOE. Model (2) presents the regression for matched firms, where the dependent variable is SEO Time; Model (3) presents the regression for matched firms, where the dependent variable is SEO relative size. SEO Time is the dependent variable and takes the value of 1 if the firm issued its first SEO within 3 years after IPO. All variables are defined in the Appendix A1. IV approach is used in this table. IPO oversubscription is used as instrumental variables. The corresponding first-stage coefficients are not reported here for space considerations. The standard errors reported in the parentheses are adjusted for heteroscedasticity. The results control for the year and industry effects. $(*)(* *)(* * *)$ indicates that the coefficient is significant at the $10 \%$ (5\%) (1\%) level, respectively.

\begin{tabular}{|c|c|c|c|}
\hline & $(1)$ & (2) & (3) \\
\hline & State Owned & SEO Time & SEO Relative Size \\
\hline IPO Underpricing & $\begin{array}{c}0.082 * * * \\
(0.015)\end{array}$ & $\begin{array}{c}0.447 * * * \\
(0.038)\end{array}$ & $\begin{array}{c}0.319 * * * \\
(0.058)\end{array}$ \\
\hline State Owned & & $\begin{array}{c}0.866 * * * \\
(0.164)\end{array}$ & $\begin{array}{c}1.415^{* * *} \\
(0.164)\end{array}$ \\
\hline IPO Underpricing*State Owned & & $\begin{array}{l}-0.100 * \\
(0.051)\end{array}$ & $\begin{array}{c}-0.274 * * * \\
(0.066)\end{array}$ \\
\hline Shanghai & $\begin{array}{c}1.002 * * * \\
(0.070)\end{array}$ & $\begin{array}{l}-0.131 \\
(0.143)\end{array}$ & $\begin{array}{c}0.308 * * \\
(0.133)\end{array}$ \\
\hline Abnormal return_1 & $\begin{array}{l}-0.302 \\
(0.264)\end{array}$ & $\begin{array}{c}0.519 \\
(0.538)\end{array}$ & $\begin{array}{c}0.415 \\
(0.526)\end{array}$ \\
\hline Abnormal return_2 & $\begin{array}{c}0.888 * * * \\
(0.291)\end{array}$ & $\begin{array}{c}1.679 * * * \\
(0.599)\end{array}$ & $\begin{array}{l}1.410 * * \\
(0.577)\end{array}$ \\
\hline Market Momentum & $\begin{array}{l}-0.104 \\
(0.066)\end{array}$ & $\begin{array}{c}-0.435^{* * *} * \\
(0.138)\end{array}$ & $\begin{array}{c}-0.363 * * * \\
(0.131)\end{array}$ \\
\hline Constant & $\begin{array}{c}-0.561 * * * \\
(0.142)\end{array}$ & $\begin{array}{c}-1.343 * * * \\
(0.300)\end{array}$ & $\begin{array}{c}-2.394 * * * \\
(0.294)\end{array}$ \\
\hline Industry \&Year & Yes & Yes & Yes \\
\hline Observations & 1708 & 1254 & 1254 \\
\hline Adjusted $\mathrm{R}^{2}$ & 0.123 & 0.065 & 0.095 \\
\hline F test/chi2 & $277.56 * * *$ & $260.14 * * *$ & $149.44 * * *$ \\
\hline
\end{tabular}


Table IA.5: Effect of IPO underpricing on first SEO issuance.

The table reports regression results exploring the impact of IPO underpricing and other control variables on SEO Time for a sample of Chinese firms over the period 2005 to

2015. SEO Time takes the value of 1 if the firm issue SEO within 3 years after IPO. All variables are defined in the Appendix A1. Three estimation procedures are used:

Logit estimation (Column 1), MLE (Column 2) and 2SLS-IV approach (Columns 3). The standard errors reported in the parentheses are adjusted for heteroscedasticity. The

results control for the year and industry effects. * $(* *)(* * *)$ indicates that the coefficient is significant at the $10 \%(5 \%)(1 \%)$ level, respectively.

\begin{tabular}{|c|c|c|c|c|c|}
\hline \multirow[b]{2}{*}{ Dependent Variable } & \multirow{2}{*}{$\begin{array}{r}\text { (1) Logit } \\
\text { SEO Time }\end{array}$} & \multicolumn{2}{|c|}{ (2) MLE } & \multicolumn{2}{|c|}{ (3) IV } \\
\hline & & $\begin{array}{c}1^{\text {st }} \text { Stage } \\
\text { IPO Underpricing }\end{array}$ & $\begin{array}{l}2^{\text {nd }} \text { Stage } \\
\text { SEO Time } \\
\end{array}$ & $\begin{array}{c}1^{\text {st }} \text { Stage } \\
\text { IPO Underpricing }\end{array}$ & $\begin{array}{l}2^{\text {nd }} \text { Stage } \\
\text { SEO Time } \\
\end{array}$ \\
\hline IPO Underpricing & $\begin{array}{c}0.527 * * * \\
(0.106)\end{array}$ & & $\begin{array}{c}0.548 * * \\
(0.242)\end{array}$ & & $\begin{array}{c}0.668 * * * \\
(0.123)\end{array}$ \\
\hline Shanghai & $\begin{array}{c}-2.894 * * * \\
(1.014)\end{array}$ & $\begin{array}{c}0.049 \\
(0.053)\end{array}$ & $\begin{array}{c}-3.001 * * * \\
(1.140)\end{array}$ & $\begin{array}{c}0.236^{* * *} \\
(0.085)\end{array}$ & $\begin{array}{c}-1.337 * * * \\
(0.407)\end{array}$ \\
\hline Abnormal return_1 & $\begin{array}{l}1.701 * * \\
(0.676)\end{array}$ & $\begin{array}{c}-0.634 * * * \\
(0.125)\end{array}$ & $\begin{array}{l}1.732^{*} \\
(0.965)\end{array}$ & $\begin{array}{c}-0.910 * * * \\
(0.170)\end{array}$ & $\begin{array}{c}1.346^{* * * *} \\
(0.421)\end{array}$ \\
\hline Abnormal return_2 & $\begin{array}{l}1.764 * * \\
(0.729)\end{array}$ & $\begin{array}{c}-0.289 * * \\
(0.134)\end{array}$ & $\begin{array}{l}1.836^{*} \\
(1.019)\end{array}$ & $\begin{array}{l}-0.259 \\
(0.187)\end{array}$ & $\begin{array}{c}1.190 * * * \\
(0.445)\end{array}$ \\
\hline Market Momentum & $\begin{array}{l}-0.259 \\
(0.175)\end{array}$ & $\begin{array}{c}-0.068^{*} \\
(0.035)\end{array}$ & $\begin{array}{l}-0.285 \\
(0.216)\end{array}$ & $\begin{array}{c}-0.106^{* *} \\
(0.044)\end{array}$ & $\begin{array}{l}-0.126 \\
(0.106)\end{array}$ \\
\hline IPO Oversubscription & & $\begin{array}{c}0.355^{* * *} \\
(0.016)\end{array}$ & & $\begin{array}{c}0.408 * * * \\
(0.021)\end{array}$ & \\
\hline Constant & $\begin{array}{c}-1.792 * * * \\
(0.415)\end{array}$ & $\begin{array}{c}-1.159 * * * \\
(0.087)\end{array}$ & $\begin{array}{l}-1.635 \\
(2.785)\end{array}$ & $\begin{array}{l}1.361 * * * \\
(0.143)\end{array}$ & $\begin{array}{c}-1.323 * * * \\
(0.257)\end{array}$ \\
\hline Industry \&Year & Yes & Yes & Yes & Yes & Yes \\
\hline Observations & 807 & 1068 & 807 & 1068 & 807 \\
\hline $\begin{array}{l}\mathrm{LR} \mathrm{Chi}^{2} \\
\text { (Pseudo) Adj_R }\end{array}$ & $\begin{array}{c}66.53 * * * \\
0.075\end{array}$ & & & 0.347 & \\
\hline Wald test & & & $10.92 * *$ & & $55.26 * * *$ \\
\hline Hausman test & & & & $11.23 * * *$ & \\
\hline First-stage F-statistics & & & & $72.41 * * *$ & \\
\hline
\end{tabular}


Table IA.6: Effect of IPO underpricing on SEO proceeds.

This table reports how IPO underpricing and other control variables affect SEO Relative Size for the sample of Chinese firms over the period 2005 to 2015. SEO Relative Size is the ratio of proceeds from the first SEO divided by proceeds from the IPO; This is equal to 0 if the firm has not processed an SEO. All variables are defined in the Appendix A1. In order to control potential endogeneity issues, three estimation procedures are used: Tobit estimation (Column 1), MLE (Column 2) and 2SLS-IV approach (Columns 3). The standard errors reported in the parentheses are adjusted for heteroscedasticity. The results control for the year and industry effects. ${ }^{*}(* *)(* *)$ indicates that the coefficient is significant at the $10 \%$ $(5 \%)(1 \%)$ level, respectively.

(2) MLE

$1^{\text {st }}$ Stage

IPO Underpricing

$2^{\text {nd }}$ Stage

SEO Relative Size

$1^{\text {st }}$ Stage

(3) IV

SEO Relative Size

IPO Underpricing

$2^{\text {nd }}$ Stage

SEO Relative Size

IPO Underpricing

$0.938 * * *$

(0.110)

Shanghai

Abnormal return_1

Abnormal return_2

Market Momentum

$\begin{array}{cc}-3.083^{* * *} & -0.289 * * \\ (0.779) & (0.134) \\ 1.605^{* *} & -0.634^{* * *} \\ (0.699) & (0.125) \\ 1.426^{*} & 0.049 \\ (0.743) & (0.053) \\ -0.515^{* * *} & -0.068^{*} \\ (0.181) & (0.035) \\ & 0.355^{* * *} \\ -1.319^{* * *} & (0.016) \\ (0.420) & -1.159 * * * \\ & (0.087)\end{array}$

Industry \&Year

Observations

LR Chi ${ }^{2}$

(Pseudo) Adj_R ${ }^{2}$

\section{Yes}

807
$29.78 * * *$

0.082

Wald test

Hausman test

First-stage F-statistics

$0.635^{* * *}$
$(0.059)$
$-0.286 * * *$
$(0.067)$
$0.480 * * *$
$(0.163)$
$0.346^{* *}$
$(0.171)$
$-0.107 * *$
$(0.045)$

0.070
$(0.051)$

$1.771 * * *$

(0.221)

$-2.918 * * *$

(0.774)

$\begin{array}{cc}(0.085) & (0.774) \\ -0.910 * * * & 2.335 * * *\end{array}$

$\begin{array}{cc}-0.910^{* * *} & 2.335^{* * *} \\ (0.170) & (0.736)\end{array}$

$-0.259 \quad 1.671 * *$

$(0.187) \quad(0.766)$

$-0.106 * * \quad-0.418 * *$

$(0.044) \quad(0.186)$

$0.408 * * *$

(0.021)

$1.361 * * * \quad-1.953 * * *$

$(0.143) \quad(0.459)$

Yes Yes

Yes

Yes

807

1068

807

0.347

$122.76^{* * *}$
$31.26 * * *$

$72.41 * * *$ 
Table IA.7: The Sources of SEO Relative Size: Heckman Procedure.

Using the sample of Chinese firms over the period 2005 to 2015, this table reports the determinants of SEO relative size, including IPO underpricing, SEO characteristics and corporate governance. Model (1) presents the OLS results, which includes firms with SEO issuance only. Model (2) presents the estimation results of Heckman two-stage procedure to address the sample selection bias. IPO underpricing, State Owned, Shanghai, Abnormal return_l and Abnormal return_2 are used to specify the selection equation in which SEO Time is the dependent variable. This variable in the outcome equation is SEO Relative Size, which is the ratio of proceeds from the first SEO divided by proceeds from the IPO. Inverse Mill's ratio is generated via the logit model to detect the presence of self-selection bias, which is then passed into the outcome equation. All variables are defined in the Appendix A1. The standard errors reported in the parentheses are adjusted for heteroscedasticity. The results control for the year and industry effects. $*(* *)(* * *)$ indicates that the coefficient is significant at the $10 \%(5 \%)(1 \%)$ level, respectively.

\begin{tabular}{|c|c|c|c|c|}
\hline \multirow[b]{2}{*}{ Dependent Variable } & \multirow{2}{*}{$\begin{array}{c}\text { (1) OLS } \\
\text { SEO Relative } \\
\text { Size } \\
\end{array}$} & \multicolumn{2}{|c|}{ (2) IV } & \multirow{2}{*}{$\begin{array}{c}\text { (3) Heckman } \\
\text { SEO Relative Size }\end{array}$} \\
\hline & & $\begin{array}{c}1^{\text {st }} \text { Stage } \\
\text { IPO Underpricing }\end{array}$ & $\begin{array}{c}2^{\text {nd }} \text { Stage } \\
\text { SEO Relative Size }\end{array}$ & \\
\hline IPO Underpricing & $\begin{array}{c}0.253 * * * \\
(0.066)\end{array}$ & & $\begin{array}{c}0.417 * * * \\
(0.126)\end{array}$ & $\begin{array}{c}0.343 * * * \\
(0.106)\end{array}$ \\
\hline Shanghai & $\begin{array}{l}-0.450 \\
(1.059)\end{array}$ & $\begin{array}{l}-0.093 \\
(0.933)\end{array}$ & $\begin{array}{l}-0.694 \\
(1.089)\end{array}$ & $\begin{array}{c}0.973 \\
(1.139)\end{array}$ \\
\hline Abnormal return_1 & $\begin{array}{l}-0.458 \\
(0.505)\end{array}$ & $\begin{array}{c}-1.252 * * * \\
(0.428)\end{array}$ & $\begin{array}{l}-0.227 \\
(0.537)\end{array}$ & $\begin{array}{l}-1.092 \\
(0.752)\end{array}$ \\
\hline Abnormal return_2 & $\begin{array}{l}-0.099 \\
(0.524)\end{array}$ & $\begin{array}{l}-0.375 \\
(0.452)\end{array}$ & $\begin{array}{l}-0.010 \\
(0.531)\end{array}$ & $\begin{array}{l}-0.833 \\
(0.761)\end{array}$ \\
\hline Market Momentum & $\begin{array}{c}0.096 \\
(0.132)\end{array}$ & $\begin{array}{c}-0.245^{* *} \\
(0.113)\end{array}$ & $\begin{array}{c}0.151 \\
(0.137)\end{array}$ & $\begin{array}{c}0.233 \\
(0.166)\end{array}$ \\
\hline SEO Leverage & $\begin{array}{c}0.053 \\
(0.091)\end{array}$ & $\begin{array}{c}0.018 \\
(0.079)\end{array}$ & $\begin{array}{c}0.032 \\
(0.092)\end{array}$ & $\begin{array}{c}0.051 \\
(0.102)\end{array}$ \\
\hline Market_to_Book & $\begin{array}{c}0.027 \\
(0.047)\end{array}$ & $\begin{array}{c}0.033 \\
(0.041)\end{array}$ & $\begin{array}{c}0.009 \\
(0.048)\end{array}$ & $\begin{array}{c}0.039 \\
(0.046)\end{array}$ \\
\hline Underwriter Reputation_SEO & $\begin{array}{l}-0.039 \\
(0.133)\end{array}$ & $\begin{array}{c}0.049 \\
(0.115)\end{array}$ & $\begin{array}{l}-0.074 \\
(0.135)\end{array}$ & $\begin{array}{l}-0.002 \\
(0.130)\end{array}$ \\
\hline Board Independence & $\begin{array}{l}-0.743 \\
(1.480)\end{array}$ & $\begin{array}{l}-1.004 \\
(1.283)\end{array}$ & $\begin{array}{l}-0.834 \\
(1.493)\end{array}$ & $\begin{array}{c}0.514 \\
(1.499)\end{array}$ \\
\hline CEO Ownership & $\begin{array}{l}-0.755^{*} \\
(0.445)\end{array}$ & $\begin{array}{c}0.276 \\
(0.391)\end{array}$ & $\begin{array}{l}-0.654 \\
(0.451)\end{array}$ & $\begin{array}{l}-0.708 * \\
(0.429)\end{array}$ \\
\hline Concentration & $\begin{array}{l}0.013 * * \\
(0.006)\end{array}$ & $\begin{array}{l}-0.009 * \\
(0.005)\end{array}$ & $\begin{array}{l}0.015^{* *} \\
(0.006)\end{array}$ & $\begin{array}{c}0.009 \\
(0.006)\end{array}$ \\
\hline Board Size & $\begin{array}{l}-0.025 \\
(0.053)\end{array}$ & $\begin{array}{l}-0.019 \\
(0.046)\end{array}$ & $\begin{array}{l}-0.032 \\
(0.053)\end{array}$ & $\begin{array}{l}-0.048 \\
(0.053)\end{array}$ \\
\hline IPO Oversubscription & & $\begin{array}{c}0.476^{* * *} \\
(0.051)\end{array}$ & & \\
\hline Constant & $\begin{array}{c}0.845 \\
(0.959)\end{array}$ & $\begin{array}{l}-0.873 \\
(0.883)\end{array}$ & $\begin{array}{c}1.263 \\
(1.013)\end{array}$ & $\begin{array}{c}2.041 \\
(1.382)\end{array}$ \\
\hline Inverse Mill's ratio & & & & $\begin{array}{c}0.768 * * * \\
(0.283)\end{array}$ \\
\hline Industry \&Year & Yes & Yes & Yes & Yes \\
\hline Observations & 231 & 231 & 231 & 807 \\
\hline Adjusted $\mathrm{R}^{2}$ & 0.059 & 0.305 & 0.044 & \\
\hline Chi2/ F-test & $2.21 * *$ & & $1.93 * *$ & $20.33^{*}$ \\
\hline Hausman test & & $39.38 * * *$ & & \\
\hline First-stage F-statistics & & $11.98 * * *$ & & \\
\hline
\end{tabular}


Table IA.8: IPO performance impact on SEO issuance decisions: the relevance of the State ownership

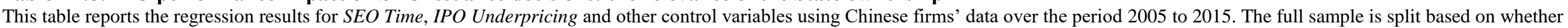

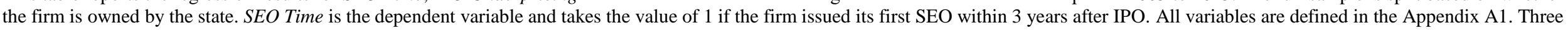
estimation procedures are used: Logit (Panel A), Maximum likelihood (Panel B) and generated IV approach (Panel C). IPO oversubscription is used as instrumental variables in the MLE and IV

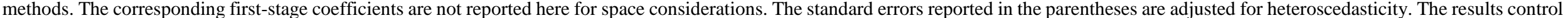
for the year and industry effects. $(*)(* *)(* * *)$ indicates that the coefficient is significant at the $10 \%(5 \%)(1 \%)$ level, respectively.

\begin{tabular}{|c|c|c|c|c|c|c|c|c|c|}
\hline & \multicolumn{3}{|c|}{ Panel A. Logit } & \multicolumn{3}{|c|}{ Panel B. MLE } & \multicolumn{3}{|c|}{ Panel C. IV } \\
\hline & $(1)$ & (2) & (3) & $(4)$ & $(5)$ & $(6)$ & $(7)$ & $(8)$ & (9) \\
\hline & $\begin{array}{c}\text { State } \\
\text { Owned }\end{array}$ & $\begin{array}{c}\text { non-State } \\
\text { Owned }\end{array}$ & Full sample & $\begin{array}{c}\text { State } \\
\text { Owned }\end{array}$ & $\begin{array}{c}\text { non-State } \\
\text { Owned }\end{array}$ & Full sample & State Owned & $\begin{array}{c}\text { non-State } \\
\text { Owned }\end{array}$ & Full sample \\
\hline IPO Underpricing & $\begin{array}{l}-0.919 * \\
(0.506)\end{array}$ & $\begin{array}{c}0.610^{* * *} \\
(0.115)\end{array}$ & $\begin{array}{c}0.624 * * * \\
(0.114)\end{array}$ & $\begin{array}{l}-0.850 \\
(0.502)\end{array}$ & $\begin{array}{c}0.607 * * * \\
(0.114)\end{array}$ & $\begin{array}{c}1.407 * * * \\
(0.265)\end{array}$ & $\begin{array}{l}-0.460 \\
(0.430)\end{array}$ & $\begin{array}{c}0.784 * * * \\
(0.132)\end{array}$ & $\begin{array}{c}0.816^{* * *} \\
(0.142)\end{array}$ \\
\hline State Owned & & & $\begin{array}{c}0.969 * * \\
(0.469)\end{array}$ & & & $\begin{array}{l}1.909 * \\
(1.011)\end{array}$ & & & $\begin{array}{c}0.819 * * * \\
(0.285)\end{array}$ \\
\hline IPO Underpricing*State Owned & & & $\begin{array}{c}-1.223^{* *} \\
(0.481)\end{array}$ & & & $\begin{array}{c}-2.491 * * * \\
(0.911)\end{array}$ & & & $\begin{array}{c}-1.134 * * * \\
(0.289)\end{array}$ \\
\hline Shanghai & $\begin{array}{l}-2.566^{*} \\
(1.327)\end{array}$ & . & $\begin{array}{c}-2.938 * * * \\
(1.022)\end{array}$ & $\begin{array}{l}-1.882 * \\
(1.126)\end{array}$ & $\begin{array}{c}-12.974 \\
(197.352)\end{array}$ & $\begin{array}{c}-5.905 * * * \\
(1.802)\end{array}$ & $\begin{array}{c}-1.390 * * \\
(0.696)\end{array}$ & . & $\begin{array}{c}-1.394 * * * \\
(0.440)\end{array}$ \\
\hline Abnormal return_1 & $6.952 * *$ & $1.517 * *$ & $1.893 * * *$ & $7.333^{* *}$ & $1.430 * *$ & $3.953 * * *$ & $3.961 * *$ & $1.352 * * *$ & $1.529 * * *$ \\
\hline Abnormal return_2 & $\begin{array}{l}(2.987) \\
-1.982 \\
(3.222)\end{array}$ & $\begin{array}{l}(0.717) \\
1.895 * * \\
(0.773)\end{array}$ & $\begin{array}{l}(0.685) \\
1.635^{* *} \\
(0.736)\end{array}$ & $\begin{array}{l}(2.994) \\
-0.616 \\
(2.965)\end{array}$ & $\begin{array}{l}(0.712) \\
1.931^{* *} \\
(0.769)\end{array}$ & $\begin{array}{c}(1.495) \\
3.585^{* *} \\
(1.611)\end{array}$ & $\begin{array}{l}(1.767) \\
-1.489 \\
(1.939)\end{array}$ & $\begin{array}{c}(0.455) \\
1.264 * * * \\
(0.477)\end{array}$ & $\begin{array}{l}(0.434) \\
1.048^{* *} \\
(0.451)\end{array}$ \\
\hline Market Momentum & $\begin{array}{c}0.550 \\
(0.739)\end{array}$ & $\begin{array}{c}-0.337^{*} \\
(0.184)\end{array}$ & $\begin{array}{l}-0.259 \\
(0.177)\end{array}$ & $\begin{array}{c}0.775 \\
(0.704)\end{array}$ & $\begin{array}{c}-0.340^{*} \\
(0.184)\end{array}$ & $\begin{array}{c}-0.655^{*} \\
(0.377)\end{array}$ & $\begin{array}{c}0.309 \\
(0.420)\end{array}$ & $\begin{array}{l}-0.152 \\
(0.114)\end{array}$ & $\begin{array}{l}-0.107 \\
(0.108)\end{array}$ \\
\hline Constant & $\begin{array}{c}0.374 \\
(1.441)\end{array}$ & $\begin{array}{c}-2.026^{* * *} \\
(0.459)\end{array}$ & $\begin{array}{c}-1.802 * * * \\
(0.417)\end{array}$ & $\begin{array}{l}-1.171 \\
(1.585)\end{array}$ & $\begin{array}{c}-1.301^{* * *} \\
(0.159)\end{array}$ & $\begin{array}{c}-3.694^{* * *} \\
(0.857)\end{array}$ & $\begin{array}{c}0.183 \\
(0.943)\end{array}$ & $\begin{array}{c}-1.494 * * * \\
(0.283)\end{array}$ & $\begin{array}{c}-1.389^{* * * *} \\
(0.264)\end{array}$ \\
\hline Industry \&Year & Yes & Yes & Yes & Yes & Yes & Yes & Yes & Yes & Yes \\
\hline Observations & 84 & 685 & 807 & 84 & 723 & 1068 & 84 & 685 & 807 \\
\hline LR Chi²/Wald $\mathrm{Chi}^{2}$ & $17.31 * * *$ & $47.52 * * *$ & $74.80 * * *$ & $17.21 * *$ & $68.24 * * *$ & $78.35 * * *$ & $11.41^{*}$ & $49.94 * * *$ & $58.54 * * *$ \\
\hline
\end{tabular}


Table IA.9: IPOs performance impact on SEO proceeds.

This table compares the impact of IPO Underpricing on SEO Relative Size between state owned firms and the non-state owned firm. Using the sample of Chinese firms over the period 2005 to 2015, we present regression results of three estimation procedures: Tobit (Panel A), Maximum likelihood (Panel B) and generated IV approach (Panel C). All variables are defined in the Appendix A1. IPO oversubscription is used as instrumental variables in the MLE and IV methods. SEO Relative Size is the dependent variable and it is the ratio of proceeds arising from the first SEO divided by proceeds raise through the IPO. All variables are defined in the Appendix A1. The standard errors reported in the parentheses are adjusted for heteroscedasticity. The results control for the year and industry effects. * $\left.{ }^{* *}\right)(* * *)$ indicates that the coefficient is significant at the $10 \%(5 \%)(1 \%)$ level, respectively

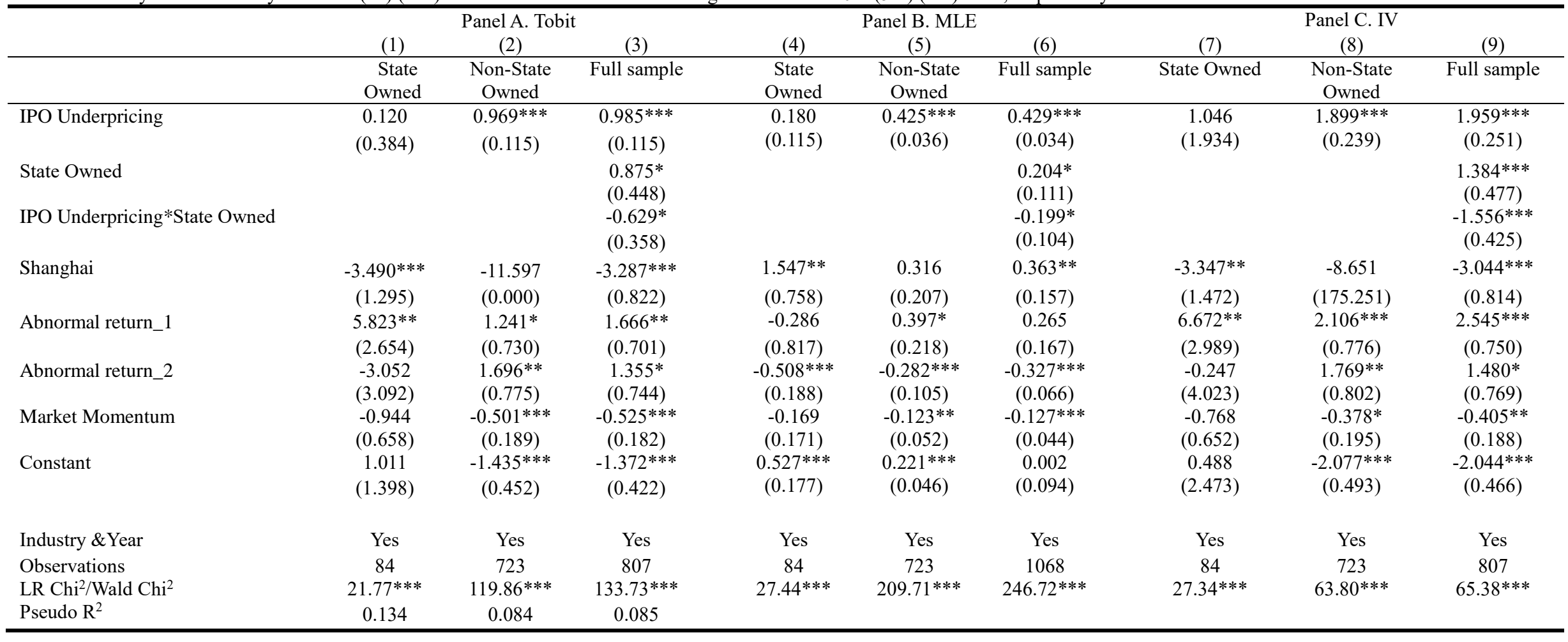


Table IA.10: Distribution of state ownership for IPOs

This table shows the ranges of share ownership held by the state for Chinese listed firms over the period from 1990 to 2015.

\begin{tabular}{cccc}
\hline Range of Ownership & Firms & Percentage & Cumulative Percentage \\
\hline $90-100$ & 312 & 18.27 & 18.27 \\
$80-89.99$ & 69 & 4.04 & 22.31 \\
$70-79.99$ & 69 & 4.04 & 26.35 \\
$60-69.99$ & 83 & 4.86 & 31.21 \\
$50-59.99$ & 76 & 4.45 & 35.66 \\
$40-49.99$ & 61 & 3.57 & 39.23 \\
$30-39.99$ & 38 & 2.22 & 41.45 \\
$20-29.99$ & 35 & 2.05 & 43.50 \\
$10-19.99$ & 40 & 2.34 & 45.84 \\
$0-9.99$ & 925 & 54.16 & 100.00 \\
Total & 1,708 & 100.00 & \\
\hline
\end{tabular}

